http://www.anpad.org.br/bar

BAR, Rio de Janeiro, v. 11, n. 4, art. 3, pp. 407-440, Oct./Dec. 2014

http://dx.doi.org/10.1590/1807-7692bar2014130012

\title{
Intangible Assets and Superior and Sustained Performance of Innovative Brazilian Firms
}

Márcia Martins Mendes De Luca E-mail address: marciammdeluca@gmail.com Universidade Federal do Ceará - FEAAC/UFC Av. da Universidade, 2431, 60020-180, Fortaleza, CE, Brazil.

Anna Beatriz Grangeiro Ribeiro Maia E-mail address: deluxedama@hotmail.com

Universidade Federal do Ceará - UFC Av. da Universidade, 2431, 60020-180, Fortaleza, CE, Brazil.

Vanessa Ingrid da Costa Cardoso E-mail address: nessaingrid@gmail.com

Universidade Federal do Ceará -UFC Av. da Universidade, 2431, 60020-180, Fortaleza, CE, Brazil.

Alessandra Carvalho de Vasconcelos E-mail address: alevasconcelos.ufc@gmail.com

Universidade Federal do Ceará -UFC Av. da Universidade, 2431, 60020-180, Fortaleza, CE, Brazil.

Jacqueline Veneroso Alves da Cunha

E-mail address: jvac@face.ufmg.br

Universidade Federal de Minas Gerais - FACE/UFMG Av. Antônio Carlos, 6627, Pampulha, 31270-901, Belo Horizonte, MG, Brazil.

Received 20 August 2013; received in revised form 21 June 2014 (this paper has been with the authors for three revisions); accepted 23 June 2014; published online $1^{\text {st }}$ October 2014. 


\begin{abstract}
According to the Resource-Based View, the nature of the resources, competences and knowledge accumulated by firms are the major causes of variation in business performance. In view of the importance attributed to intangible assets, the purpose of the present study was to investigate whether innovative firms with superior and sustained performance and firms without superior and sustained performance differ with regard to investments in intangible assets. The sample consisted of 137 firms listed on the Brazilian stock exchange from 2007 to 2010 and belonging to innovative sectors according to the Brazilian Innovation Index. Only 51 firms with profitability above the sector average during the entire study period (four years) met the criterion of superior and sustained performance. Thus, using return on assets as a proxy for performance, investments in intangibles were found to be greater in firms without superior and sustained performance, particularly with regard to the categories intellectual property assets (the predominant category) and infrastructure assets. Based on the lack of evidence for a significant correlation between corporate performance and investment in intangible assets, our initial hypothesis that a positive relation exists between the composition of investments in intangible assets and the performance of innovative firms could not be confirmed.
\end{abstract}

Key words: resource-based view; intangible assets; business performance; superior and sustained performance; innovative firms. 


\section{Introduction}

Scholars have long discussed the characteristics and peculiarities of firms which display superior and sustained performance. Many theories have been put forth to identify the determining factors and basic characteristics required to measure and improve business performance. One such theory is the Resource-Based View (RBV), according to which the nature of a firm's resources and accumulated competences are the main cause of variation in performance. To Barney (1991), tangible and intangible resources, combined with competences and controlled by the firm, make it possible to create and implement efficient strategies capable of producing organizational improvements in the long run. Thus, differences in performance between organizations derive from the heterogeneity of their resources (Peteraf, 1993). Scholars such as Wernerfelt (1984), Barney (1991), Peteraf (1993), Teece, Pisano and Shuen (1997) and Penrose (2006) defend the adoption of RBV tenets to maintain long-term sustainable competitive advantage.

Seen from this perspective, resources and competences are distributed heterogeneously among the firms of a given sector as a result of differences in each firm's history and background. Each firm's uniqueness makes it difficult to replicate its resources by acquisition or substitution, creating a potential for competitive advantage (Barney, 1991) and, consequently, superior and sustained performance, at least until its competitors obtain a comparable array of resources (Brito \& Vasconcelos, 2004; Carvalho, Kayo, \& Martín, 2010).

Intangible assets are resources and competences which may be combined to boost corporate performance. Iudícibus, Martins, Gelbcke, and Santos (2013) point out that while tangible assets are visually identifiable and segregated items in accounting, intangible assets may not be so. Brazilian legislation (Lei n. 11.638, 2007) considers intangible assets incorporeal property destined and used for the maintenance of the firm. In 2008, during the convergence on international accounting standards, the Brazilian Accounting Pronouncements Committee published Technical Statement \#4 (Comitê de Pronunciamentos Contábeis [CPC], 2008), subsequently modified by CPC \#4/R1/2010 (CPC, 2010), defining intangible assets as identifiable non-monetary assets without physical substance. It should be pointed out that the adoption of international accounting standards in Brazil, starting in 2007, is reflected in the peculiar way in which intangible assets are incorporated in the structure of the balance sheet, where they are given the status of noncurrent assets, and in the way their fair value is determined, which in turn influences the way the indicators of an organization's assets are calculated.

Hoog (2008) sees intangible assets as property without physical substance, the useful life of which tends to be subjective, varying according to the rights resulting from ownership and the associated competitive advantages and profits, which may be acquired or developed internally.

To Edvinsson and Malone (1998), Stewart (1999) and Santos and Schmidt (2002), intangible assets are synonymous with intellectual capital or knowledge assets. They add value to the organization and are part of its base of knowledge and information. Thus, for the purpose of this study, the expressions knowledge management, knowledge assets, intangible assets, intangible capital, intangible resources, intellectual capital, goodwill, occult capital, invisible assets and intellectual property refer to the same type of asset, as shown by similarities between the definitions proposed by different authors (Antunes, 2006; Brooking, 1996; Carvalho \& Ensslin, 2006; Edvinsson \& Malone, 1998; Kaufmann \& Schneider, 2004; Lev, 2001; Petty \& Guthrie, 2000; Rezende, 2001; Stewart, 1999; Sveiby, 1997).

With regard to the strategic role of intellectual capital and knowledge management, Rezende (2001, p. 17) stated that "knowledge management is the process of creating value through the use of the organization's intangible assets; it is the transformation of information into knowledge, and of knowledge into business". This is the definition adopted in our study.

Regardless of the nomenclature and definitions assigned to intangible assets, in the perspective of RBV this type of asset is generally seen as the main source of competitive advantage because it is inimitable, specific, rare and valuable for the organization (Teixeira \& Popadiuk, 2003). The 
combination of intangible assets consequently improves business performance and competitive advantage. Thus, Kaplan and Norton (1996), Nonaka and Takeuchi (1997), Sveiby (1997), Stewart (1999) and Lev (2001), among others, believe intangible assets are the main factor responsible for the creation of competitive advantage (or disadvantage) in an organization. In other words, a considerable part of the variation in corporate wealth is attributed to intangible assets and their use.

However, results from studies on intangible assets have not always been consistent. Thus, while Villalonga (2004) and Perez and Famá (2006) concluded intangible assets significantly contributed to the superior and sustained performance of US firms, Carvalho, Kayo and Martín (2010) reported opposite effects on Brazilian firms, concluding investments in intangible assets were actually negatively associated with business performance. However, the result of the study may have been influenced by the setting in which it was conducted: the sample consisted of firms from several sectors listed on the Brazilian stock exchange (BM\&FBovespa).

Peteraf (1993) defines competitive advantage as sustained, above-normal returns. To Barney and Hesterly (2007), a firm achieves competitive advantage when it creates more economic value than the competitors in its sector or product market. Silva (2009) described a line of research focused on sustained extraordinary profits based on earlier studies by Brozen (1971) and Mueller (1977), who empirically evaluated firms with persistently better results than those of their competitors, that is, with better performance over an extended period of time, and concluded that the abnormal returns observed at a given moment in time were due to some extraordinary factor impacting all firms simultaneously.

According to McGahan and Porter (2002), the persistence of abnormal returns is related to sector and company characteristics, since convergences on abnormal returns are sector and company-specific. The authors also demonstrated that business-specific effects represented by competitive position and other factors influence corporate performance.

These same issues were addressed by Bou and Satorra (2007) in a study of Spanish firms. The authors found that abnormal returns occur when, at a given moment, profit rates vary greatly between firms and sectors and are identified most prominently in organizations whose performance is well above average.

In view of this, despite difficulties in classifying Brazilian innovative firms (Oyadomari, Cardoso, Silva, \& Perez, 2010), the sample of the present study consisted of potentially innovative firms included in the Brazilian Innovation Index (Índice Brasil de Inovação [IBI]). The index was developed by the State University of Campinas (Universidade Estadual de Campinas [UNICAMP]), the UNIEMP Institute and the São Paulo State Foundation for Research Aid (Fundação de Amparo à Pesquisa do Estado de São Paulo [FAPESP]), based on results from studies indicating an association between intangible assets and innovative capacity. According to the third edition of the Oslo Manual (which contains guidelines for the collection and interpretation of information on innovation, published in 2005 by the Organization for Economic Co-Operation and Development [OECD]), innovation requires considerable investments, including the acquisition of intangible assets with potential long-term return. In addition, in a study published by the Institute of Applied Economics (Instituto de Pesquisa Econômica Aplicada, a public foundation affiliated with the Department of Strategic Affairs of the Brazilian presidency), Tironi and Cruz (2008) highlighted the importance of intangible assets for corporate innovation in the era of knowledge economics and stated that higher levels of innovation require a greater predominance of intangible assets in the innovation process.

Thus, in this study we attempt to answer the question: What is the relation between the composition of investments in intangible assets of innovative firms and corporate performance?. The objective of the study was to investigate whether innovative firms with superior and sustained performance and firms without superior and sustained performance differ with regard to investments in intangible assets. In addition, the relation between investments in intangible assets and the performance of innovative firms was evaluated. Inclusion in IBI level of innovativeness was used as a proxy for innovation capacity. The following hypothesis was formulated: 
Hypothesis: A positive relation exists between the composition of investments in intangible assets and the performance of innovative firms.

We adopted the classification proposed by Brooking (1996) which segregates intangible assets into market assets, human-centered assets, intellectual property assets and infrastructure assets. Over the past decade, this classification has been employed by a number of researchers (Bollen, Vergauwen, \& Schnieders, 2005; Kot, 2009; Marr, Schiuma, \& Neely, 2004) and in a wide range of empirical settings (Antunes, 2005; Antunes \& Leite, 2008; Santos, Silva, Gallon, \& De Luca, 2011). Furthermore, in view of the study objectives and the importance of collecting corporate data as objective and representative of reality as possible, we used the information on investments in intangible assets provided in the accounting statements of the sampled firms under the heading intangible assets, in accordance with international accounting regulations recently adopted in Brazil (CPC, 2010).

The study is intended to subsidize the current discussion on intangible assets in specific business contexts (sector and region) by evaluating Brazilian firms in innovative sectors (according to the IBI), characterized as intangible asset-intensive (Kayo, 2002). The approach is itself innovative in that firms with and without superior and sustained performance are compared with regard to investments in intangible assets segregated by category (Brooking, 1996).

\section{Review of the Literature}

In this section, we outline the main aspects of superior and sustained business performance, the relation between performance and intangible assets, and the theoretical framework adopted in the study.

\section{Superior and sustained performance and RBV}

In today's globalized market, all firms are compelled to outperform their competitors. However, for some firms, positive results per se are not enough, especially if they do not reflect perpetual growth.

Firms and sectors are not homogeneous but are subject to many types of variation which can interfere directly with performance (Brito \& Vasconcelos, 2004). Researchers of different schools have studied the question of heterogeneity in business performance, but the criteria with which to measure performance remains a matter of controversy (Carvalho et al., 2010). The notion that firms are essentially heterogeneous with regard to resources and internal capacities has guided much of the research in this field (Peteraf, 1993).

Carneiro, Silva, Rocha and Dib (2007) observed that research on the determining factors of business performance has yielded conflicting or inconsistent results, possibly due to poor construct conceptualization, operationalization and measurement of business performance.

According to Neely, Gregory and Platts (1995), the evaluation of performance may literally be defined as the process of quantifying action, where measurement is the process of quantification and action leads to performance. This is the definition adopted in the present study. On the other hand, as Mintzberg (1973) pointed out, while measuring may be a process of quantification, it also stimulates action. It is only through consistency of action and decision that organizational strategies are realized.

Kimura and Suen (2003, p. 4) believe it is useful to evaluate organizational performance; however, "the complexity of the interactions between the variables that determine business performance calls for the development of special management tools for decision making". Methodical and automated analyses can help prevent rash decisions and conflicting strategies.

In order to systematically monitor how resources are allocated and converted in operational action for the attainment of the organization's goals, firms must measure their performance (Schmidt, 2002). 
In fact, the measuring of performance may be seen as fundamental to the long-term maintenance and survival of the firm in the context of global business competition.

Measures of business performance should be expressed with a metrics which can be interpreted and used by stakeholders. Despite recognizing the procedure is complex and may involve different types of measures, El-Shishini (2001) and Omaki (2005) pointed out that "researches highlighted that financial measures are the most commonly used parameters" (El-Shishini, 2001, and Omaki, 2005, as cited in Carvalho et al., 2010, p. 874) as they are generally believed to be the most reasonable estimates of organizational performance. However, not all scholars agree with this view.

The Resource-Based View (RBV) is based on the recognition of individual and unique resources in each firm and on the ability of such factors to explain variation in business performance (Carvalho et al., 2010). The main cause of variation in organizational performance is related to the specific nature of the firm's resources and accumulated competences. RBV strategies are based on the notion that competitive advantage is derived from the organization's ability to adequately combine and exploit tangible and intangible resources (Wernerfelt, 1984). Thus, firms with superior organizational structure and management systems may obtain extraordinary profits by exploiting resources of which there is a scarcity on the market (Oening, 2010).

Several analyses and models of sustained superior performance and related factors have been published. In a seminal study on the principles of RBV, Penrose (1959) showed that corporate growth is determined by managerial competence, acquired experience and learning capacity while using internal and external resources. On the other hand, Schmalensee (1985) looked into the influence of the economic sector and market share on fluctuations in corporate profits based on data from a single fiscal year. Considering a somewhat longer period (4 years), Rumelt (1991) emphasized breaking down the components of the observed variance in corporate return rates.

Kor and Mahoney (2004) discussed a number of studies dealing with different aspects of corporate growth and performance, highlighting Penrose's study (1959) which contributed significantly to the development of RBV by providing a fundamental logical framework for understanding the causal relations between resources, capacities and competitive advantage. According to the authors (Kor \& Mahoney, 2004), Penrose (1959) considered three explanatory factors regarding the relation between corporate resources, productive opportunities and growth: (a) efficient and innovative resource management, (b) causal relations between resources and the generation of productive opportunities for expansion and innovation, and (c) availability of managerial talent and techniques, the lack of which is sometimes the primary bottleneck to a firm's growth.

For the purpose of this study, superior and sustained performance was defined as long-term financial performance (Rumelt, 1991) above the average in a given sector (Schmalensee, 1985). The factors determining such performance are seen in light of RBV. In a study on RBV, Grant (1991) stressed that, by focusing on unique resources and competences, organizations can build a solid foundation on which to strengthen their identity, develop long-term strategies and define their primary source of income. Many of these resources and competences would take the form of intangible assets, as indicated by Penrose (1959).

\section{Intangible assets and superior performance}

In view of the growing interest in the subject of intangible assets, a range of different approaches have been proposed. Table 1 summarizes the main approaches to intangible assets as observed in the literature. 
Table 1

Different Views of Intangible Assets

\begin{tabular}{|c|c|}
\hline Authors & Approach to intangible assets \\
\hline Kohler (1957) & $\begin{array}{l}\text { A capital asset without physical substance, the value of which is defined by rights } \\
\text { and claims to expected benefits. }\end{array}$ \\
\hline Brooking (1996) & $\begin{array}{l}\text { Synonymous with intellectual capital, the result of changes in IT, media and } \\
\text { communications, providing intangible benefits and enabling firms to function. }\end{array}$ \\
\hline $\begin{array}{l}\text { Edvinsson and Malone } \\
\text { (1998) }\end{array}$ & $\begin{array}{l}\text { The notion of intangible assets arose in response to the growing awareness of the } \\
\text { role of non-accounting factors in actual company value. }\end{array}$ \\
\hline $\begin{array}{l}\text { Hendriksen and Van } \\
\text { Breda (1999) }\end{array}$ & $\begin{array}{l}\text { Intangible assets are among the most complex issues in accounting because } \\
\text { uncertainties about how to define them and measure their value and useful life. }\end{array}$ \\
\hline Lev (2001) & $\begin{array}{l}\text { Rights and claims to expected benefits without physical or financial substance } \\
\text { originating from discoveries, organizational practices and human resources. }\end{array}$ \\
\hline Hillman and Keim (2001) & $\begin{array}{l}\text { Intangible assets strengthen relations with the community through socio- } \\
\text { environmental actions, reflected in financial benefits to stockholders. }\end{array}$ \\
\hline Kayo (2002) & $\begin{array}{l}\text { A structured set of knowledge, practices and attitudes interacting with the } \\
\text { organization's tangible assets to compound company value. }\end{array}$ \\
\hline $\begin{array}{l}\text { Schmidt and Santos } \\
(2002)\end{array}$ & $\begin{array}{l}\text { Incorporeal resources controlled by the firm from which potential future benefits } \\
\text { may be derived. }\end{array}$ \\
\hline $\begin{array}{l}\text { Teixeira and Popadiuk } \\
\text { (2003) }\end{array}$ & $\begin{array}{l}\text { Intangible assets help boost corporate performance to the extent they are valuable, } \\
\text { unique and difficult to imitate. }\end{array}$ \\
\hline Perez and Famá (2006) & $\begin{array}{l}\text { Permanent assets without physical substance, at the disposal of and controlled by } \\
\text { the firm, a source of potential future benefits. }\end{array}$ \\
\hline Lei n. 11.638 (2007) & $\begin{array}{l}\text { Rights and claims to incorporeal property destined and used for the maintenance of } \\
\text { the firm, including acquired goodwill. }\end{array}$ \\
\hline $\operatorname{Hoog}(2008)$ & $\begin{array}{l}\text { Incorporeal property with a frequently subjective useful economic life varying } \\
\text { according to the rights resulting from ownership and the associated competitive } \\
\text { advantages and profits, which may be acquired or developed internally. }\end{array}$ \\
\hline $\begin{array}{l}\text { International Accounting } \\
\text { Standards } 38 \text { (n.d.), CPC } \\
(2010)\end{array}$ & Non-monetary assets without physical substance also referred to as goodwill. \\
\hline $\begin{array}{l}\text { Surroca, Tribó and } \\
\text { Waddock (2010) }\end{array}$ & Intangible assets consolidate the means of creating financial earnings. \\
\hline $\begin{array}{l}\text { Machado and Famá } \\
\text { (2011) }\end{array}$ & $\begin{array}{l}\text { Permanent non-physical assets which, together with tangible assets, are capable of } \\
\text { producing future benefits. }\end{array}$ \\
\hline Lima and Carmona (2011) & $\begin{array}{l}\text { Intangible assets correspond to the difference between total value (defined by the } \\
\text { market) and book value as stated in the balance sheet. }\end{array}$ \\
\hline $\begin{array}{l}\text { Teixeira, Petri and } \\
\text { Marques (2012) }\end{array}$ & $\begin{array}{l}\text { Nowadays, intangible assets comprise the values previously classified as } \\
\text { incorporeal fixed assets. }\end{array}$ \\
\hline Iudícibus et al. (2013) & $\begin{array}{l}\text { Aggregated assets of future economic benefits to be controlled and exploited } \\
\text { exclusively by a given organization. }\end{array}$ \\
\hline
\end{tabular}

Note. Source: Composed by the authors, based on a review of the literature.

In this study, we adopted the view that intangible (or intellectual) assets are resources without physical substance, therefore difficult to measure, at the disposal of the firm, from which future economic benefits may be derived. Examples of intangible assets include patents, franchises, brands, 
goodwill, authors' rights, secret processes, licenses, developed software, data bases, public concessions, rights to exploitation or operation, portfolios of captive customers, etc. (Perez \& Famá, 2006).

To Lev (2001), intangible assets have three main attributes: network externality, non-rivalry and unlimited scalability. Network externality is the influence of the initial consumption of an individual user on the total demand for a product or service. The term non-rivalry is applied to assets when its use by one person or organization does not prevent its simultaneous use by others. Unlimited scalability refers to the return on an intangible asset by increasing scale (Carvalho et al., 2010).

Many authors, such as Flamholtz (1985), Chauvin and Hirschey (1993), Megna and Klock (1993), Nonaka and Takeuchi (1997), Sveiby (1997), Kaplan and Norton (1996), Edvinsson and Malone (1998), Stewart (1999), Lev (2001), Kayo, Teh and Basso (2004), Villalonga (2004), Connolly and Hirschey (2005), Perez and Famá (2006), Ensslin and Carvalho (2007), Gallon, Lyrio and Ensslin (2008), Crisóstomo (2009), Kayo, Patrocínio and Martin (2009) and Surroca et al. (2010) have demonstrated the influence of intangible or intellectual assets on the creation of wealth and pointed out the positive relations between investment in innovation-related resources and corporate market value. Other studies focus on the representativeness of intangible assets in corporate structure, especially Colauto, Nascimento, Avelino and Bispo (2009), Carvalho et al. (2010), Ritta and Ensslin (2010), Santos, Silva, Gallon and De Luca (2012), Nascimento, Oliveira, Marques and Cunha (2012), Santos, Vasconcelos and De Luca (2013) and Vasconcelos, Santos, De Luca and Cunha (2013).

Three studies on the relation between intangible assets and superior and sustained performance are of particular relevance: Villalonga (2004) compared the return on assets (ROA) of each firm in a sample of US firms to the respective sector average and found intangible assets to have a significant influence on superior performance, thereby concluding intangibility was responsible for sustained performance. Likewise, Perez and Famá (2006) observed that in US firms tangible assets were only responsible for regular earnings, while new value was added by intangible assets. Conversely, in a sample of Brazilian firms, Carvalho et al. (2010) found a negative correlation between intangible resources and superior and sustained performance, thereby rejecting the initial hypothesis of their study.

Other international studies worthy of mention have contributed to consolidating the tenets of RBV. In a study on the RBV model from the early 1990s, Grant (1991) concluded that corporate resources and capacities are essential to the building of strategies capable of increasing return rates. The author believes the essence of RBV is in the perception of the relations between resources, capacities, competitive advantage and profitability in each firm. This perception is crucial to achieving competitive advantage in the long term.

In a recent study, Petkov (2011) explored conceptual issues related to the identification of intangible assets generated internally and recognized in financial statements, highlighting the need for periodical analysis of such assets for corporate sustainability. In their study on IT-related assets, Ray, Xue and Barney (2013) observed that IT capital has an effect on corporate performance to the extent that these assets expand the firm's possibilities of vertical integration and product market diversification. In addition, Ulrich and Smallwood (2005) looked at intangible assets from the perspective of human resources and found this aspect to be crucial to the creation of company value. By implementing human resources actions, a firm can create sustainable intangible values, which in turn help capitalize it on the market.

In the present study, we assumed that intangible innovation assets have a significant influence on the maintenance of superior and sustained business performance. Lee and Chen (2009) observed that, for example, investments in R\&D can affect company value and were in fact associated with expectations of a significant increase and creation of value. However, according to Carvalho et al. (2010), the potential of intangible assets to create wealth for the organization depends on their specific attributes.

Recently published studies suggest that the relation between innovation and the creation of value in firms may not be uniform (Carvalho et al., 2010). Since the publication in 1962 of the Frascati Manual 
(and in its wake a number of OECD-sponsored publications) and the publication in 1990 of the Oslo Manual, the notion of innovation has been informed and standardized by concepts, methodologies and the development of statistics and indicators for research on R\&D in industrialized countries (OECD, 2005). The Oslo Manual (OECD, 2005) defines innovation as the implementation/commercialization of a product, process, marketing method or business practice with improved performance characteristics affecting the organization of the firm and its external relations.

For the purpose of this study, we composed a sample of Brazilian public firms from the BM\&FBovespa stock exchange included in the sectors identified by the IBI as the most innovative. We adopted the classification of intangible assets proposed by Brooking (1996, p. 136) which features a specific category related to innovation, namely "intellectual property assets".

Due to the difficulty in classifying innovative Brazilian firms (Oyadomari et al., 2010), we adopted the levels of innovativeness used in the 2007 edition of the IBI (developed by UNICAMP/UNIEMP/FAPESP) to compose Table 9. To Basso and Kimura (2010, p. 97), "the IBI sector classification is validated by the existence of an expressive difference in innovation effort and results between the sectors, in support of the RBV concept that individual firms are unique within their respective sector". The IBI was adopted specifically to select sectors of relevance to our study on innovative Brazilian firms because it is a well-established market indicator. As pointed out by Camargo (2008), the IBI is a tool with which firms can compare their innovative performance to that of their competitors. Since its introduction, the IBI has been used by a number of Brazilian researchers (Basso \& Kimura, 2010; Inácio \& Quadros, 2008; Lopes \& Barbosa, 2010; Oyadomari et al., 2010; Ramos, 2008).

Upon the initiative of Revista Inovação (a journal published by the Uniemp Institute), the IBI project was developed in 2005 by researchers of the UNICAMP Department of S\&T Policies (Departamento de Política Científica e Tecnológica/Instituto de Geociências [DPCT/IG]), with the support of FAPESP. Designed to measure capacity for innovation, the IBI was used to establish a ranking of innovative Brazilian firms (Furtado, Quadros, Domingues, Camillo, Inácio, \& Righetti, 2007).

The IBI methodology derives from well-established data collection methodologies and systems, and provides a comprehensive approach to corporate innovativeness. The main set of data used in the IBI model are retrieved from the database of Research in Technological Innovation (Pesquisa de Inovação [PINTEC]), an initiative of the Brazilian Institute of Geography and Statistics (Instituto Brasileiro de Geografia e Estatística [IBGE]) with support from the Studies and Projects Financing Agency (Financiadora de Estudos e Projetos [FINEP]), which was instrumental in showing the relevance of gathering statistical information on firms (Furtado, Quadros, Righetti, Inácio, Domingues, \& Camillo, 2007). PINTEC uses the methodology of the Oslo Manual (OECD, 2005) for research on innovation and quantifies R\&D in a way consistent with the Frascati Manual. To evaluate innovation capacity in the form of patents, the IBI retrieves publicly available data from the National Institute of Industrial Property (Instituto Nacional da Propriedade Industrial [INPI]) (Furtado, Quadro, Domingues et al., 2007).

Due to its importance at the national level, Ramos (2008) compares the IBI (Furtado \& Quadros, 2006; Quadros \& Furtado, 2007) to well-established international indices, such as the UN-sponsored Technology Achievement Index (TAI) (United Nations Development Programme [UNDP], 2001), the OECD-sponsored Composite of Innovation Performance (Freundenberg, 2003) and the Japanese Overall Science and Technology Index (National Institute of Science and Technology Policy [NISTEP], 1995).

In this study, our objective was to analyze the composition of the intangible assets of a sample of Brazilian public firms belonging to sectors defined by the IBI as innovative and evaluate potential associations between asset composition and business performance, based on previous empirical studies and considering the characteristics and specificities of each category of assets. 


\section{Methodology}

In order to give a detailed description of intangibility and superior and sustained business performance in a sample of Brazilian public firms and define relations between study variables, the collected information consisted of corporate financial data retrieved from the Economática ${ }^{\circledR}$ database and from explanatory notes in standard financial reports and statements posted on the website of the BM\&FBovespa stock exchange.

The sample consisted of public firms traded on BM\&FBovespa as of April 2010, classified by the IBI as innovative. According to Carvalho et al. (2010), studies on intangibility and superior and sustained performance yield more meaningful results when based on samples covering particularly innovative business sectors. Based on PINTEC data 2005 (IBGE, 2006), the IBI was highlighted in studies by Furtado and Quadros (2006), Inácio and Quadros (2006), Furtado, Quadros, Righetti et al. (2007), Furtado, Quadros and Domingues (2007), Quadros and Furtado (2007), Righetti and Pallone (2007), Camargo (2008) and Rocha (2009) and has been employed in several other studies, such as Inácio and Quadros (2008), Ramos (2008), Lopes and Barbosa (2010), Oyadomari, Cardoso, Silva and Perez (2010) and Basso and Kimura (2010).

Financial data and information on asset composition were available for 137 of a sample of 174 innovative Brazilian firms. Thus, the final sample included 137 firms, distributed according to the sector classification adopted by BM\&FBovespa and IBI level of innovativeness: high-tech (Group 1), medium high-tech (Group 2), medium low-tech (Group 3) and low-tech (Group 4) (Table 2).

Table 2

Classification of the 137 Firms in the Sample According to Sector and IBI Level of Innovativeness

\begin{tabular}{lccccc}
\hline Sector & $\begin{array}{c}\text { Group 1: } \\
\text { high-tech }\end{array}$ & $\begin{array}{c}\text { Group 2: } \\
\text { medium } \\
\text { high-tech }\end{array}$ & $\begin{array}{c}\text { Group 3: } \\
\text { medium low- } \\
\text { tech }\end{array}$ & $\begin{array}{c}\text { Group 4: } \\
\text { low-tech }\end{array}$ & Total \\
\hline Capital goods and services & 13 & 12 & - & - & $\mathbf{2 5}$ \\
Construction and transportation & - & - & 3 & - & $\mathbf{3}$ \\
Cyclical consumption & - & 4 & 20 & 3 & $\mathbf{2 7}$ \\
Non-cyclical consumption & - & - & 1 & 20 & $\mathbf{2 1}$ \\
Basic materials & - & 10 & 6 & 18 & $\mathbf{3 4}$ \\
Oil, gas and biofuels & - & 4 & - & - & $\mathbf{4}$ \\
IT & 7 & - & - & - & $\mathbf{7}$ \\
Telecommunications & - & 16 & - & - & $\mathbf{1 6}$ \\
Total & 20 & 46 & 30 & 41 & 137 \\
\hline
\end{tabular}

Note. Source: The authors.

For the purpose of this study, superior and sustained performance was taken to imply aboveaverage performance over a period of four or more years (Carvalho et al. 2010). The study period therefore comprised four years of financial exercise (ending in 2007, 2008, 2009 and 2010). According to Rumelt (1991), four years is long enough to reflect the effects of an entire business cycle. In addition, the study period covers the adaptation of Brazilian firms to the newly introduced international accounting standards which, since the 2010 fiscal year, require firms to list intangible assets in financial statements (Macedo, Machado, Machado, \& Mendonça, 2013; Santos, 2012). 
Only firms with profitability (as expressed by ROA) above the sector average during the entire study period (considering the sector average of each of the four years covered by the study) met the criterion of superior and sustained performance. Thus, firms with one or more years of financial performance below the sector average were not considered to have superior and sustained performance. The choice of ROA in this study is justified by the extensive applicability of this indicator in studies on corporate performance (Almeida \& Santos, 2008; Bomfim, Almeida, Gouveia, Macedo, \& Marques, 2011; Bortoluzzi, Lyrio, \& Ensslin, 2008; Carvalho et al., 2010; Roberts \& Dowling, 2002). According to Silva (2009), ROA reflects the efficiency of operations based on a firm's assets in accounting. The indicator may be interpreted as the maximum financial cost incurred by a firm in its external funding operations; in other words, if the rate obtained in external funding operations exceeds the ROA, the shareholders' return is reduced (Assaf, 2009). Thus, in detriment to other possible variables, ROA was adopted as a measure of performance based on several studies discussed above. Furthermore, the choice of ROA is consistent with the study objective of evaluating the relation between superior and sustained performance and investments in intangible assets in the study period.

Initially, we collected financial data for each firm in the sample. Information on profitability was retrieved from Economática ${ }^{\circledR}$. Subsequently, content analysis (Richardson, 2007) was applied to information on intangible asset composition extracted from the explanatory notes in each firm's accounting statements. Values representing property items (intangible assets and total assets) were converted into USD at the exchange rate in effect upon the closing of the balance sheet of each year of exercise, while earnings were converted into USD at the average exchange rate of each period, as specified in International Accounting Standard 21 (2003). The variable representing the composition of investments in intangible assets was operationalized based on the amount indicated in the financial statements as invested in intangible assets each year of the study period. It should be added that our choice of measure of investment in intangible assets, as registered in corporate accounting statements and explanatory notes, was based on several Brazilian and international studies on intangibles in which the measure was deemed appropriate and objective (Carvalho et al., 2010; Connolly \& Hirschey, 2005; Crisóstomo, 2009; Kayo, Patrocínio, \& Martin, 2009; Megna \& Klock, 1993; Perez \& Famá, 2006; Villalonga, 2004).

Our analysis of the intangible asset composition was based on the classification proposed by Brooking (1996, p. 136) which features a specific category related to innovation, namely "intellectual property assets" (Table 3$)$.

Table 3

Intangible Asset Composition, Based on Brooking (1996)

\begin{tabular}{ll}
\hline Classification & Composition \\
\hline Market assets & Company potential derived from market-related intangible assets. \\
$\begin{array}{l}\text { Human-centered } \\
\text { assets }\end{array}$ & $\begin{array}{l}\text { Company potential derived from the expertise, creativity, knowledge and problem- } \\
\text { solving skills of individuals, considered collectively and dynamically. }\end{array}$ \\
$\begin{array}{l}\text { Intellectual property } \\
\text { assets }\end{array}$ & Assets that require legal protection in order to benefit organizations. \\
Infrastructure assets & $\begin{array}{l}\text { Technologies, methodologies and processes, such as organizational culture, information } \\
\text { systems, management methods, risk acceptance, customer databases etc. }\end{array}$ \\
\hline
\end{tabular}

Note. Source: Adapted from Brooking, A. (1996). Intellectual capital: core asset for the third millennium enterprise. Boston: Thomson Publishing Inc.

Data extracted from explanatory notes included information on intangible assets segregated by category and indicator, rather than simply registering the total monetary value, of the group. The classification used was that of Brooking (1996) (Table 4). 
Table 4

Indicators of Intangible Assets Classified According to Brooking (1996)

\begin{tabular}{ll}
\hline Classification & Indicator \\
\hline Market assets & $\begin{array}{l}\text { Goodwill, customer portfolios, program contracts (commitment), program } \\
\text { contracts (investments made), cost of removing property and reforestation, } \\
\text { negative goodwill, expenditure on acquisitions and equity, brands, allowance for } \\
\text { losses. }\end{array}$ \\
Human-centered assets & $\begin{array}{l}\text { Acquisition of payroll. } \\
\text { Intellectual property assets }\end{array}$ \\
& $\begin{array}{l}\text { Concessions, exclusive agreements, acquired software, software licenses, other } \\
\text { acquired rights, product research and development, technology, patents, } \\
\text { completed projects. }\end{array}$ \\
Infrastructure assets & $\begin{array}{l}\text { Expenditure on shopfitting, expenditure on ongoing projects, setup of facilities } \\
\text { on third-party premises, sales outlets, system implementation projects, distance- } \\
\text { learning projects, administrative services, information systems, software, } \\
\text { preoperational expenses. }\end{array}$ \\
Other.
\end{tabular}

Note. Source: The authors.

The classification human-centered assets has only one indicator, while market assets, intellectual property assets and infrastructure assets have 10,9 and 10 indicators, respectively. Indicators not classifiable elsewhere in the framework are listed under the heading other intangibles.

The statistical techniques adopted were consistent with the study objectives and included calculating mean values and correlation coefficients and performing regression analyses in order to test for differences between innovative firms with superior and sustained performance and firms without superior and sustained performance with regard to investments in intangible assets, and to verify the existence of a relation between investments in intangible assets and corporate performance during a period of four years. Intangible assets were expressed in relative measures in the statistical analysis due to the inclusion of firms of varying size in the sample. Thus, the value of the intangible assets was divided by total company assets, and outliers were removed from the sample.

The normality of the data was initially verified with the Kolmogorov-Smirnov test. Subsequently, the data were analyzed with the Mann-Whitney test in order to compare firms with and without superior and sustained performance with regard to the composition of intangible assets throughout the 4-year study period. According to Fávero, Belfiore, Silva and Chan (2009, p. 163), Mann-Whitney is used "to test whether two samples of independent observations represent populations with equal mean values". The test detects differences or similarities between the mean values of the two samples (in this case, firms with and without superior and sustained performance).

To test the hypothesis, the level of statistical significance was set at $5 \%(p<0.05)$. The finding of significant differences $(p<0.05)$ between firms with and without superior and sustained performance with regard to mean values of intangible assets implies the rejection of the null hypothesis.

Due to the non-normal distribution of the sample, a non-parametric test (Spearman's correlation coefficient) was used in the correlation analysis.

Also adopted in the study, regression analysis is used to investigate the relation between two or more explanatory variables presented in linear form (Fávero, Belfiore, Silva, \& Chan, 2009), thereby allowing verification of the existence of a significant association between a dependent variable (in the present study, corporate performance) and one or more independent variables (in the present study, total investment in intangible assets, investments in intangible assets by category adopted in this study, and 
control variables represented by size, sector and classification of innovation according to the IBI) (Cunha \& Coelho, 2007).

Thus, in order to present more consistent results for the relation between intangible assets and corporate performance, we developed three regression models represented by the following equations:

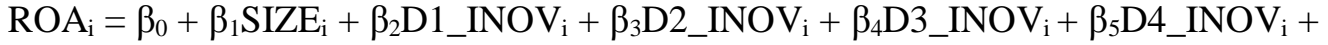

$$
\begin{aligned}
& \beta_{6} \mathrm{D} 1 \_I N D_{i}+\beta_{7} \mathrm{D} 2 \_I N D_{i}+\beta_{8} \mathrm{D} 3 \_I N D_{i}+\beta_{9} \mathrm{D} 4{ }_{-} \mathrm{IND}_{\mathrm{i}}+\beta_{10} \mathrm{D}_{-} \mathrm{IND}_{\mathrm{i}}+\beta_{11} \mathrm{D}_{-} \mathrm{IND}_{\mathrm{i}}+ \\
& \beta_{12} \mathrm{D} 7 \_\mathrm{IND} \mathrm{i}_{\mathrm{i}}+\beta_{13} \mathrm{D} 8 \text { INND }+\varepsilon \\
& \text { ROA }_{i}=\beta_{0}+\beta_{1} \text { MARK }_{i}+\beta_{2} \mathrm{INT}_{\mathrm{i}}+\beta_{3} \mathrm{D} 2 \mathrm{INFRA}_{\mathrm{i}}+\beta_{4} \mathrm{D} 3 \mathrm{OTH}_{\mathrm{i}}+\beta_{5} \mathrm{SIZE}_{\mathrm{i}}+ \\
& \beta_{6} \mathrm{D} 1 \_\mathrm{INOV} \mathrm{V}_{\mathrm{i}}+\beta_{7} \mathrm{D} 2 \_\mathrm{INOV} \text { i }+\beta_{8} \mathrm{D} \text { 3 } \_I N O V_{i}+\beta_{9} \mathrm{D} 4 \mathrm{INOV}_{\mathrm{i}}+\beta_{10} \mathrm{D} 1 \mathrm{IND}_{\mathrm{i}}+\beta_{11} \mathrm{D} 2 \_\mathrm{IND}_{\mathrm{i}}+ \\
& \beta_{12} \mathrm{D} 3 \text { INDD }+\beta_{13} \mathrm{D} 4 \_I N D_{i}+\beta_{14} \mathrm{D} 5 \text { INDD } i+\beta_{15} \mathrm{D}_{-} \mathrm{IND}_{\mathrm{i}}+\beta_{16} \mathrm{D} 7 \_\mathrm{IND}_{\mathrm{i}}+\beta_{17} \mathrm{D} 8 \_\mathrm{IND}_{\mathrm{i}}+\varepsilon \\
& \text { ROA }_{i}=\beta_{0}+\beta_{1} \text { TOTALINT }_{i}+\beta_{2} \text { SIZE }_{i}+\beta_{3} \text { D1 }_{-} \text {INOV }_{i}+\beta_{4} \mathrm{D} 2 \text { INOV }_{i}+\beta_{5} \mathrm{D}_{-} \text {INOV }_{\mathrm{i}} \\
& +\beta_{6} \mathrm{D} 4 \mathrm{INOV}_{\mathrm{i}}+\beta_{7} \mathrm{D} 1 \mathrm{IND}_{\mathrm{i}}+\beta_{8} \mathrm{D} 2 \mathrm{IND}_{\mathrm{i}}+\beta_{9} \mathrm{D} 3 \mathrm{IND}_{\mathrm{i}}+\beta_{10} \mathrm{D} 4{ }_{-} \mathrm{IND}_{\mathrm{i}}+\beta_{11} \mathrm{D} \text { IIND }_{\mathrm{i}}+ \\
& \beta_{12} \mathrm{D} 6 \_\mathrm{IND} \mathrm{i}_{\mathrm{i}}+\beta_{13} \mathrm{D} 7 \mathrm{IND}_{\mathrm{i}}+\beta_{14} \mathrm{D} 8 \text { _IND } \mathrm{IN}_{\mathrm{i}}+\varepsilon
\end{aligned}
$$

Table 5 shows the variables used in the present study.

Table 5

Variables

\begin{tabular}{lll}
\hline \multicolumn{1}{c}{ Variable } & \multicolumn{1}{c}{ Description } & \multicolumn{1}{c}{ Metric } \\
\hline ROA & Performance & Net earnings / Total assets \\
TOTALINT & Total intangible assets & Total investments in assets \\
MARK & Market assets BRL & Investments in market assets \\
INTEL & Intellectual property assets BRL & Investments in intellectual property assets \\
INFRA & Infrastructure assets BRL & Investments in infrastructure assets \\
OTHER & Other intangibles BRL & Investments in other intangibles \\
SIZE & Company size & Logarithm of asset \\
D1_INOV & Dummy innovation group 1 & 1 for firms in Group 1 \\
D2_INOV & Dummy innovation group 2 & 1 for firms in Group 2 \\
D3_INOV & Dummy innovation group 3 & 1 for firms in Group 3 \\
D4_INOV & Dummy innovation group 4 & 1 for firms in Group 4 \\
D1_IND & Dummy capital goods and services industry & 1 for firms in capital goods and services \\
& sector \\
D2_IND & Dummy construction and transportation & 1 for firms in construction and transportation \\
D3_IND & industry & sector \\
D4_IND & Dummy cyclical consumption industry & 1 for firms in cyclical consumption sector \\
D5_IND & Dummy basic materials industry & 1 for firms in non-cyclical consumption \\
D6_IND & Dummy oil, gas and biofuels industry & 1 for firms in oil, gas and biofuels sector \\
D7_IND & Dummy information technology industry & 1 for firms in information technology sector \\
D8_IND & Dummy telecommunications industry & 1 for firms in telecommunications sector \\
\hline Note.Sol consumption industry & sector \\
\hline
\end{tabular}

Note. Source: The authors. 
Data analysis was performed with the software SPSS ${ }^{\circledR}$ (Statistical Package for the Social Sciences) and Stata. The results of the test of normality (Kolmogorov-Smirnov), comparison of means (Mann-Whitney), correlation (Spearman) and multiple linear regression analysis are presented and analyzed below.

\section{Presentation and Analysis of Results}

Initially, it should be pointed out that intangible assets were only taken into account when monetary values were assigned to them in the sampled accounting statements. Once a monetary value had been identified in a company's explanatory notes, information was collected regarding the composition and definition of each asset (Table 3) and the indicators of intangible assets classified according to Brooking (1996) (Table 4).

To help understand the content analysis of the explanatory notes performed in view of the study objectives, the indicators of the intangible assets in each category identified in the explanatory notes (Brooking, 1996; Table 4) are listed in Table 6 along with examples of the terminology employed by the sampled firms in their disclosure of intangible assets in explanatory notes of accounting statements covering the period 2007-2010.

Table 6

Indicators of Intangible Assets (Brooking, 1996) and Examples of the Terminology Employed by the Sampled Firms in Their Disclosure of Intangible Assets in Explanatory Notes (EN) of Accounting Statements Covering the Period 2007-2010

\begin{tabular}{|c|c|c|}
\hline Category & $\begin{array}{l}\text { Indicators of intangible } \\
\text { assets, according to Brooking } \\
\text { (1996), identified in EN }\end{array}$ & $\begin{array}{l}\text { Terminology employed by the sampled firms in their } \\
\text { disclosure of intangible assets in EN }\end{array}$ \\
\hline \multirow[t]{10}{*}{ Market assets } & \multirow[t]{10}{*}{$\begin{array}{l}\text { Goodwill resulting from } \\
\text { expected future profitability }\end{array}$} & $\begin{array}{l}\text { Ágio na Aquisição de Companhias - EN from 2007, Totvs } \\
\text { S.A. (note 10, p. 17); }\end{array}$ \\
\hline & & $\begin{array}{l}\text { Ágio em Controladas - EN from 2008, São Paulo Alpargatas } \\
\text { S.A. (note 10, p. 6); }\end{array}$ \\
\hline & & $\begin{array}{l}\text { Ágios na Incorporação/Aquisição - EN from 2008, Unipar } \\
\text { Carbocloro S.A. (note 14, p. 22); }\end{array}$ \\
\hline & & $\begin{array}{l}\text { Ágio na Aquisição de Controladas - EN from 2009, MMX } \\
\text { Mineração e Metálicos S.A. (note 17, p. 26); NE from } 2009 \text {, } \\
\text { Weg S.A. (note 13, p. 10); }\end{array}$ \\
\hline & & $\begin{array}{l}\text { Ágio de Aquisição - EN from 2009, Telefônica Brasil S.A. } \\
\text { (note 13, p. 19); }\end{array}$ \\
\hline & & $\begin{array}{l}\text { Ágio na Aquisição de Empresas - EN from 2009, Springs } \\
\text { Global Participações S.A. (note 10, p. 15); }\end{array}$ \\
\hline & & $\begin{array}{l}\text { Ágio na Aquisição de Participação - EN from 2010, Iochpe- } \\
\text { Maxion S.A. (note 12, p. 67); }\end{array}$ \\
\hline & & $\begin{array}{l}\text { Ágio Fundamentado em Rentabilidade Futura - EN from } \\
\text { 2010, Braskem S.A. (note 15, p. 75); }\end{array}$ \\
\hline & & $\begin{array}{l}\text { Ágio Pago em Aquisições - EN from 2010, Usinas Sid. de } \\
\text { Minas Gerais S.A./Usiminas (note 19, p. 107); }\end{array}$ \\
\hline & & $\begin{array}{l}\text { Ágio - EN from 2010, Forjas Taurus S.A. (note 16, p. 38); EN } \\
\text { from 2010, Tim Participações S.A. (note 17, p. 47) }\end{array}$ \\
\hline
\end{tabular}




\section{Table 6 (continued)}

\begin{tabular}{|c|c|c|}
\hline Category & $\begin{array}{l}\text { Indicators of intangible } \\
\text { assets, according to Brooking } \\
\text { (1996), identified in EN }\end{array}$ & $\begin{array}{l}\text { Terminology employed by the sampled firms in their } \\
\text { disclosure of intangible assets in EN }\end{array}$ \\
\hline \multirow[t]{8}{*}{ Market assets } & \multirow[t]{2}{*}{ Customer portfolios } & $\begin{array}{l}\text { Carteira de Clientes - EN from 2008, São Paulo Alpargatas } \\
\text { S.A. (note 10, p. 6); EN from 2009, Totvs S.A. (note 13, p. } \\
\text { 30); EN from 2010, Telemar Participações S.A. (note 18, p. } \\
\text { 91); }\end{array}$ \\
\hline & & $\begin{array}{l}\text { Carteira de Clientes (Rede IP) - EN from 2009, Telefônica } \\
\text { Brasil S.A. (note 13, p. 19) }\end{array}$ \\
\hline & \multirow{2}{*}{$\begin{array}{l}\text { Program contracts } \\
\text { (Commitment and investment } \\
\text { made) }\end{array}$} & $\begin{array}{l}\text { Contratos com Clientes e Fornecedores - EN from } 2010 \text {, } \\
\text { Braskem S.A. (note 15, p. 75); }\end{array}$ \\
\hline & & $\begin{array}{l}\text { Subsídios na Venda de Aparelhos e Mini Modens - EN from } \\
\text { 2010, Tim Participações S.A. (note 17, p. 47) }\end{array}$ \\
\hline & $\begin{array}{l}\text { Cost of removing property and } \\
\text { reforestation }\end{array}$ & $\begin{array}{l}\text { Custo para Retirada de Ativos e Reflorestamento - EN from } \\
\text { 2009, MMX Mineração e Metálicos S.A. (note 17, p. 26) }\end{array}$ \\
\hline & $\begin{array}{l}\text { Goodwill resulting from } \\
\text { operations }\end{array}$ & $\begin{array}{l}\text { Fundo de Comércio - EN from 2010, Portobello S.A. } 2010 \\
\text { (note 22, p. 57) }\end{array}$ \\
\hline & $\begin{array}{l}\text { Expenditure on acquisitions and } \\
\text { equity }\end{array}$ & $\begin{array}{l}\text { Intangíveis Adquiridos na Combinação de Negócios - EN } \\
\text { from 2010, Fibria Celulose S.A. (note 19, p. 75) }\end{array}$ \\
\hline & Brands & $\begin{array}{l}\text { Marcas - EN from 2007, Bematech Ind.a e Com. de } \\
\text { Equipamentos Eletrônicos S.A. (note 15, p. 16); EN from } \\
\text { 2007, Totvs S.A. (note 10, p. 17); EN from 2008, São Paulo } \\
\text { Alpargatas S.A. (note 10, p. 6); EN from 2009, Randon S.A. } \\
\text { Implementos e Participações (note 12, p. 16); EN from 2009, } \\
\text { Springs Global Participações S.A. (note 10, p. 15); EN from } \\
\text { 2010, Braskem S.A. (note 15, p. 75); EN from 2010, } \\
\text { Portobello S.A. } 2010 \text { (note 22, p. 57) }\end{array}$ \\
\hline
\end{tabular}

Human-

centered

assets

\begin{tabular}{ll}
\hline Intellectual & Concessions \\
property & Cessão de Direitos Comerciais - EN from 2010, São Paulo \\
assets & Alpargatas S.A. (note 16, p. 58); \\
& Concessão - EN from 2010, Telemar Participações S.A. (note \\
& 18, p. 91); \\
& Licenças de Concessão - EN from 2010, Tim Participações \\
& S.A. (note 17, p. 47)
\end{tabular}

Exclusive agreements

Direitos Minerários - EN from 2009, MMX Mineração e Metálicos S.A. (note 17, p. 26); EN from 2010, Usinas Sid. de Minas Gerais S.A. - Usiminas (note 19, p. 107);

Direito de Exploração de Jazidas - EN from 2010, Portobello S.A. 2010 (note 22, p. 57)

Acquired software and software Direito de Uso - EN from 2007, Bematech Ind. e Com. de licenses

Equipamentos Eletrônicos S.A. (note 15, p. 16);

Licença de Software - EN from 2009, Weg S.A. (note 13, p. 10);

Direitos de Uso de Software - EN from 2008, Unipar

Carbocloro S.A. (note 14, p. 22); EN from 2010, Tim

Participações S.A. (note 17, p. 47);

Software Direitos de Uso - EN from 2010, Braskem S.A. (note 15, p. 75) 


\section{Table 6 (continued)}

\begin{tabular}{|c|c|c|}
\hline Category & $\begin{array}{l}\text { Indicators of intangible } \\
\text { assets, according to Brooking } \\
\text { (1996), identified in EN }\end{array}$ & $\begin{array}{l}\text { Terminology employed by the sampled firms in their } \\
\text { disclosure of intangible assets in EN }\end{array}$ \\
\hline \multirow{15}{*}{$\begin{array}{l}\text { Intellectual } \\
\text { property } \\
\text { assets }\end{array}$} & \multirow[t]{7}{*}{ Other acquired rights } & $\begin{array}{l}\text { Direito de Exploração de Área - EN from 2007, Totvs S.A. } \\
\text { (note 10, p. 17); }\end{array}$ \\
\hline & & $\begin{array}{l}\text { Direitos de Uso - Adutora de Água - EN from 2008, Unipar } \\
\text { Carbocloro S.A. (note 14, p. 22); }\end{array}$ \\
\hline & & $\begin{array}{l}\text { Direitos de Exploração de Áreas e Direitos Autorais de } \\
\text { Produtos Desenvolvidos por Terceiros - EN from 2009, Totvs } \\
\text { S.A. (note 13, p. 30); }\end{array}$ \\
\hline & & Franquias - EN from 2009, Totvs S.A. (note 13, p. 30); \\
\hline & & $\begin{array}{l}\text { Direitos de Uso de Subestação de Energia - EN from 2009, } \\
\text { Randon S.A. Implementos e Participações (note 12, p. 16); }\end{array}$ \\
\hline & & $\begin{array}{l}\text { Direito de Uso de Telefone - EN from 2010, Kepler Weber } \\
\text { S.A. (note 19, p. 54); }\end{array}$ \\
\hline & & $\begin{array}{l}\text { Licenças de Uso - EN from 2010, Positivo Informática S.A. } \\
\text { (note } 14 \text {, p. 40) }\end{array}$ \\
\hline & \multirow[t]{3}{*}{$\begin{array}{l}\text { Product research and } \\
\text { development }\end{array}$} & $\begin{array}{l}\text { Desenvolvimento de Produtos - EN from 2007, Totvs S.A. } \\
\text { (note 10, p. 17); EN from 2009, Totvs S.A. (note 13, p. 30); EN } \\
\text { from 2010, Kepler Weber S.A. (note 19, p. 54); }\end{array}$ \\
\hline & & $\begin{array}{l}\text { Pesquisa e Desenvolvimento - EN from 2010, Embraer S.A. } \\
\text { (note 18, p. 45); }\end{array}$ \\
\hline & & $\begin{array}{l}\text { Pesquisa e Desenvolvimento de Novos Produtos - EN from } \\
2010 \text { do Itautec S.A. (note 15, p. 44) }\end{array}$ \\
\hline & \multirow[t]{2}{*}{ Technology } & $\begin{array}{l}\text { Tecnologia - EN from 2008, Unipar Carbocloro S.A. (note } \\
\text { 14, p. 22); }\end{array}$ \\
\hline & & $\begin{array}{l}\text { Licenças Regulatórias - EN from 2010, Telemar } \\
\text { Participações S.A. (note 18, p. 91) }\end{array}$ \\
\hline & \multirow[t]{2}{*}{ Patents } & $\begin{array}{l}\text { Patentes - EN from 2007, Totvs S.A. (note 10, p. 17); EN } \\
\text { from 2008, Unipar Carbocloro S.A. (note 14, p. 22); EN from } \\
\text { 2009, Randon S.A. Implementos e Participações (note 12, p. } \\
\text { 16); EN from 2010, DHB Indústria e Comércio S.A. (note 15, } \\
\text { p. 4); EN from 2010, Kepler Weber S.A. (note 19, p. 54); }\end{array}$ \\
\hline & & $\begin{array}{l}\text { Direitos e Patentes - EN from 2008, São Paulo Alpargatas } \\
\text { S.A. (note } 10, \text { p. } 6 \text { ) }\end{array}$ \\
\hline & Completed projects & $\begin{array}{l}\text { Projetos Concluídos - EN from 2010, DHB Indústria e } \\
\text { Comércio S.A. (note 15, p. 4) }\end{array}$ \\
\hline \multirow[t]{3}{*}{$\begin{array}{l}\text { Infrastructure } \\
\text { assets }\end{array}$} & \multirow[t]{3}{*}{$\begin{array}{l}\text { Expenditure on ongoing } \\
\text { projects }\end{array}$} & $\begin{array}{l}\text { Projetos em Andamento - EN from 2010, São Paulo } \\
\text { Alpargatas S.A. (note 16, p. 58); }\end{array}$ \\
\hline & & $\begin{array}{l}\text { Custos de Desenvolvimento - EN from 2010, Forjas Taurus } \\
\text { S.A. (note 16, p. 38); }\end{array}$ \\
\hline & & $\begin{array}{l}\text { Projetos de Desenvolvimento - EN from 2010, Positivo } \\
\text { Informática S.A. (note 14, p. 40) }\end{array}$ \\
\hline
\end{tabular}




\section{Table 6 (continued)}

\begin{tabular}{|c|c|c|}
\hline Category & $\begin{array}{l}\text { Indicators of intangible } \\
\text { assets, according to Brooking } \\
(1996) \text {, identified in EN }\end{array}$ & $\begin{array}{l}\text { Terminology employed by the sampled firms in their } \\
\text { disclosure of intangible assets in EN }\end{array}$ \\
\hline \multirow[t]{15}{*}{$\begin{array}{l}\text { Infrastructure } \\
\text { assets }\end{array}$} & \multirow[t]{2}{*}{$\begin{array}{l}\text { Setup of facilities on third-party } \\
\text { premises }\end{array}$} & $\begin{array}{l}\text { Solo Capitalizado - EN from 2008, Unipar Carbocloro S.A. } \\
\text { (note } 14, \text { p. 22); }\end{array}$ \\
\hline & & $\begin{array}{l}\text { Direitos de Uso do Termo - EN from 2010, Iochpe-Maxion } \\
\text { S.A. (note } 12, \text { p. } 67 \text { ) }\end{array}$ \\
\hline & \multirow[t]{2}{*}{ Sales outlets } & $\begin{array}{l}\text { Pontos Comerciais (Luvas) - EN from 2009, Springs Global } \\
\text { Participações S.A. (note 10, p. 15); }\end{array}$ \\
\hline & & $\begin{array}{l}\text { Bens e Instalações em Andamento - EN from 2010, Tim } \\
\text { Participações S.A. (note 17, p. 47) }\end{array}$ \\
\hline & \multirow[t]{4}{*}{ System implementation projects } & $\begin{array}{l}\text { Projetos de Tecnologia da Informação - EN from 2009, Weg } \\
\text { S.A. (note 13, p. 10); }\end{array}$ \\
\hline & & $\begin{array}{l}\text { Desenvolvimento e Implantação de Sistemas - EN from } 2010 \text {, } \\
\text { Fibria Celulose S.A. (note 19, p. } 75 \text { ); }\end{array}$ \\
\hline & & $\begin{array}{l}\text { Implantação de Sistemas - EN from 2010, Forjas Taurus S.A. } \\
\text { (note 16, p. 38); }\end{array}$ \\
\hline & & $\begin{array}{l}\text { Projetos Sistema - ERP - EN from 2010, Positivo Informática } \\
\text { S.A. (note 14, p. } 40 \text { ) }\end{array}$ \\
\hline & Information systems & $\begin{array}{l}\text { Sistema de Gestão Empresarial - EN from 2008, São Paulo } \\
\text { Alpargatas S.A. (note 10, p. 6) }\end{array}$ \\
\hline & \multirow[t]{6}{*}{ Software } & $\begin{array}{l}\text { Sistemas Aplicativos de Software - EN from 2007, Bematech } \\
\text { Ind. e Com. de Equipamentos Eletrônicos S.A. (note 15, p. } \\
\text { 16) }\end{array}$ \\
\hline & & $\begin{array}{l}\text { Software e Licenças - EN from 2009, Randon S.A. } \\
\text { Implementos e Participações (note 12, p. 16); NE de 2010, } \\
\text { Kepler Weber S.A. (note 19, p. 54); }\end{array}$ \\
\hline & & $\begin{array}{l}\text { Softwares - EN from 2009, Telefônica Brasil S.A. (note 13, p. } \\
\text { 19); EN from } 2010 \text { do Itautec S.A. (note 15, p. 44); EN from } \\
\text { 2010, Iochpe-Maxion S.A. (note 12, p. 67) }\end{array}$ \\
\hline & & $\begin{array}{l}\text { Programas de Computador (Softwares) - EN from } 2010 \text {, } \\
\text { Embraer S.A. (note 18, p. 45); }\end{array}$ \\
\hline & & $\begin{array}{l}\text { Sistemas de Processamento de Dados - EN from } 2010 \text {, } \\
\text { Telemar Participações S.A. (note 18, p. 91); }\end{array}$ \\
\hline & & $\begin{array}{l}\text { Softwares Adquiridos - EN from 2010, Usinas Sid. de Minas } \\
\text { Gerais S.A. - Usiminas (note 19, p. 107) }\end{array}$ \\
\hline \multirow[t]{3}{*}{$\begin{array}{l}\text { Other } \\
\text { intangibles }\end{array}$} & \multirow[t]{3}{*}{ Other } & $\begin{array}{l}\text { Outros - EN from 2008, Unipar Carbocloro S.A. (note 14, p. } \\
\text { 22); EN from 2009, Totvs S.A. (note 13, p. 30); EN from } \\
\text { 2010, Usinas Sid. de Minas Gerais S.A. - Usiminas (note 19, } \\
\text { p. 107); EN from 2010, Positivo Informática S.A. (note 14, p. } \\
\text { 40); }\end{array}$ \\
\hline & & $\begin{array}{l}\text { Outros Ativos Intangíveis - EN from 2010, Telemar } \\
\text { Participações S.A. (note 18, p. 91); }\end{array}$ \\
\hline & & $\begin{array}{l}\text { Outros Ativos - EN from 2010, Tim Participações S.A. (note } \\
\text { 17, p. 47) }\end{array}$ \\
\hline
\end{tabular}

Note. Source: Data collected for the study.

As may be seen from Table 6, not all the indicators of intangible assets proposed by Brooking (1996) (Table 4) were found in the explanatory notes of the accounting statements issued by the firms in the sample. For example, no mention was made of negative goodwill and allowance for losses (market 
assets), acquisition of payroll (human-centered assets) and expenditure on shopfitting, distance-learning projects, administrative services and preoperational expenses (infrastructure assets).

Some of the indicators of intangible assets (goodwill resulting from expected future profitability, brands, patents and software) were more frequently disclosed than others (such as cost of removing property and reforestation, goodwill resulting from operations, concessions, exclusive agreements, product research and development, technology, completed projects, expenditure on ongoing projects, setup of facilities on third-party premises, sales outlets, system implementation projects, and information systems).

Some of the terminology employed by the sampled firms, as displayed in Table 6 , was similar to that adopted by Brooking (1996), for example with regard to customer portfolios, brands and patents. Other indicators featured a more diversified terminology, for example with regard to goodwill resulting from expected future profitability, system implementation projects, and software. In some cases, the categories of intangible assets (Brooking, 1996) displayed in Table 3 were used to classify items extracted from the content analysis of the explanatory notes (e.g. other acquired rights, setup of facilities on third-party premises, and information systems).

Table 7 shows total values of intangible assets as disclosed in accounting statements issued over the period 2007-2010 by innovative Brazilian firms and the proportion (\%) of corporate investments in each category of assets (Brooking, 1996).

Table 7

Total Amount (USD) and Distribution of Investments in Different Categories of Intangible Assets (Brooking, 1996) in a Sample of 137 Innovative Brazilian Firms in the Period 2007-2010

\begin{tabular}{|c|c|c|c|c|c|c|}
\hline \multirow[t]{2}{*}{ Period } & \multirow{2}{*}{$\begin{array}{l}\text { Total investment } \\
\text { in intangible } \\
\text { assets }\end{array}$} & \multicolumn{5}{|c|}{ Distribution of investment in intangible assets } \\
\hline & & $\begin{array}{l}\text { Market } \\
\text { assets }\end{array}$ & $\begin{array}{l}\text { Human- } \\
\text { centered } \\
\text { assets }\end{array}$ & $\begin{array}{l}\text { Intellectual } \\
\text { property } \\
\text { assets }\end{array}$ & $\begin{array}{l}\text { Infrastructure } \\
\text { assets }\end{array}$ & $\begin{array}{c}\text { Other } \\
\text { intangibles }\end{array}$ \\
\hline \multirow[t]{2}{*}{2007} & 30127619.00 & 9298308.61 & 0 & 13788968.55 & 5710401.47 & 1329940.37 \\
\hline & $100 \%$ & $30.86 \%$ & $0.00 \%$ & $45.77 \%$ & $18.95 \%$ & $4.41 \%$ \\
\hline \multirow[t]{2}{*}{2008} & 56497608.45 & 26426011.84 & 0 & 22963556.88 & 6898746.36 & 209293.37 \\
\hline & $100 \%$ & $46.77 \%$ & $0.00 \%$ & $40.65 \%$ & $12.21 \%$ & $0.37 \%$ \\
\hline \multirow[t]{2}{*}{2009} & 120830923.20 & 60105892.90 & 0 & 50928760.70 & 9356754.27 & 439515.29 \\
\hline & $100 \%$ & $49.74 \%$ & $0.00 \%$ & $42.15 \%$ & $7.74 \%$ & $0.36 \%$ \\
\hline \multirow[t]{2}{*}{2010} & 133212366.80 & 51872838.00 & 0 & 68082271.80 & 10789474.00 & 2467783.00 \\
\hline & $100 \%$ & $38,94 \%$ & $0.00 \%$ & $51.11 \%$ & $8.10 \%$ & $1.85 \%$ \\
\hline Total & 340668517.40 & 147703051.40 & 0 & 155763557.90 & 32755376.10 & 4446532.03 \\
\hline
\end{tabular}

Note. Source: Data collected for the study.

As shown in Table 7, investments were predominantly made in intellectual property assets and market assets. Overall, an increase in intangible assets was observed, in both relative and absolute numbers, throughout the study period.

Table 8 shows the proportion (\%) of investments in each category of intangible assets (Brooking, 1996) according to IBI level of innovativeness: high-tech (Group 1), medium high-tech (Group 2), medium low-tech (Group 3) and low-tech (Group 4). 
Table 8

Distribution of Investments in Different Categories of Intangible Assets (Brooking, 1996) as Disclosed in the Accounting Statements of a Sample of 137 Innovative Brazilian Firms in the Period 2007-2010, Organized According to IBI Level of Innovativeness

\begin{tabular}{lcccccc}
\hline $\begin{array}{l}\text { IBI level of } \\
\text { innovativeness }\end{array}$ & Period & Distribution of investments in intangible assets & \\
\cline { 3 - 7 } & & Market assets & $\begin{array}{c}\text { Human- } \\
\text { centered } \\
\text { Assets }\end{array}$ & $\begin{array}{c}\text { Intellectual } \\
\text { property assets }\end{array}$ & $\begin{array}{c}\text { Infrastructure } \\
\text { assets }\end{array}$ & $\begin{array}{c}\text { Other } \\
\text { intangibles }\end{array}$ \\
\hline Group 1 & 2007 & $44.47 \%$ & $0.00 \%$ & $14.65 \%$ & $40.12 \%$ & $0.76 \%$ \\
& 2008 & $20.81 \%$ & $0.00 \%$ & $57.65 \%$ & $20.89 \%$ & $0.65 \%$ \\
& 2009 & $30.85 \%$ & $0.00 \%$ & $48.25 \%$ & $19.43 \%$ & $1.47 \%$ \\
& 2010 & $52.29 \%$ & $0.00 \%$ & $33.90 \%$ & $11.30 \%$ & $2.50 \%$ \\
\hline Group 2 & 2007 & $23.32 \%$ & $0.00 \%$ & $50.99 \%$ & $20.71 \%$ & $4.99 \%$ \\
& 2008 & $30.75 \%$ & $0.00 \%$ & $52.35 \%$ & $16.41 \%$ & $0.49 \%$ \\
& 2009 & $35.31 \%$ & $0.00 \%$ & $54.76 \%$ & $9.70 \%$ & $0.23 \%$ \\
\hline Group 3 & 2010 & $11.45 \%$ & $0.00 \%$ & $74.79 \%$ & $10.97 \%$ & $2.78 \%$ \\
\hline & 2007 & $93.57 \%$ & $0.00 \%$ & $4.17 \%$ & $2.26 \%$ & $0.00 \%$ \\
& 2008 & $87.65 \%$ & $0.00 \%$ & $5.83 \%$ & $6.52 \%$ & $0.01 \%$ \\
& 2009 & $93.58 \%$ & $0.00 \%$ & $3.12 \%$ & $3.30 \%$ & $0.01 \%$ \\
& 2010 & $61.25 \%$ & $0.00 \%$ & $9.78 \%$ & $28.96 \%$ & $0.01 \%$ \\
\hline Group 4 & 2007 & $68.93 \%$ & $0.00 \%$ & $27.11 \%$ & $1.80 \%$ & $2.16 \%$ \\
& 2008 & $85.71 \%$ & $0.00 \%$ & $13.37 \%$ & $0.84 \%$ & $0.08 \%$ \\
& 2009 & $90.13 \%$ & $0.00 \%$ & $8.06 \%$ & $1.06 \%$ & $0.75 \%$ \\
& 2010 & $88.09 \%$ & $0.00 \%$ & $10.81 \%$ & $0.96 \%$ & $0.14 \%$ \\
\hline
\end{tabular}

Note. Source: Data collected for the study.

It may be observed (Table 8 ) that investments in infrastructure assets were predominant among technology-intensive firms (Groups 1 and 2), with emphasis on investments in new stores, ongoing projects, facilities installed on third-party premises, sales outlets, implementation of systems, information systems and software. Conversely, in less technology-intensive firms (Groups 3 and 4), investments tended to concentrate on market assets, such as goodwill, brands, acquisitions and equity.

Subsequently, the numerical variables were submitted to descriptive statistical analysis according to category of intangible assets (Brooking, 1996). For this purpose, the absolute values of the intangible assets were used to ensure the analysis reflected the actual amounts invested by the firms. The results are shown in Table 9. 
Table 9

\section{Descriptive Statistics}

\begin{tabular}{lccccc}
\hline $\begin{array}{l}\text { Parameters of } \\
\text { descriptive } \\
\text { statistics }\end{array}$ & $\begin{array}{c}\text { Market } \\
\text { assets }\end{array}$ & $\begin{array}{c}\text { Intellectual } \\
\text { property } \\
\text { assets }\end{array}$ & $\begin{array}{c}\text { Infrastructure } \\
\text { assets }\end{array}$ & $\begin{array}{c}\text { Other } \\
\text { intangibles }\end{array}$ & $\begin{array}{c}\text { Total } \\
\text { intangible } \\
\text { assets }\end{array}$ \\
\hline $\begin{array}{l}\text { Number of } \\
\text { observations }\end{array}$ & 548 & 548 & 548 & 548 & 548 \\
Mean & $269,531.12$ & $284,240.07$ & $59,772.58$ & $8,114.11$ & $621,657.88$ \\
Median & 114.00 & 34.50 & 0.00 & 0.00 & $6,104.50$ \\
Standard deviation & $1,359,265.04$ & $1,468,260.50$ & $247,136.22$ & $65,081.69$ & $2,173,583.44$ \\
Coefficient of & 5.04 & 5.17 & 4.13 & 8.02 & 3.50 \\
Variation (\%) & & & & & \\
Interval & $21,610,615.00$ & $16,012,390.00$ & $3,111,134.00$ & $1,056,859.00$ & $21,607,999.00$ \\
Minimum & $-771,805.00$ & 0.00 & $-13,439.00$ & 0.00 & $-14,646.00$ \\
Maximum & $20,838,810.00$ & $16,012,390.00$ & $3,097,695.00$ & $1,056,859.00$ & $21,593,353.00$ \\
\hline
\end{tabular}

Note. Source: Data collected for the study.

The number of observations $(n=548)$ corresponds to the number of firms in the sample $(n=137)$ multiplied by the number of years $(n=4)$ in the study period. The coefficient of variation is greatest for the category other intangibles, which includes less-relevant or difficult-to-categorize assets of the public firms analyzed. Investments in infrastructure assets were the most homogeneous of the categories (Table 9). The category human-centered assets was not included in Table 6 as none of the sampled firms disclosed information on this resource, probably because human-centered assets - defined by Brooking (1996) as benefits to organizations from the expertise, creativity, knowledge and problemsolving skills of individuals, considered collectively and dynamically - can be very difficult to quantify, despite the claim by Pacheco (2005) that human capital, represented by the set of skills and knowledge available to an organization, can be measured and disclosed.

The highest mean values were observed for intellectual property assets, closely followed by market assets, indicating a preference in our sample of innovative firms for investment in these two categories of intangible assets.

Table 10 shows the number of firms with and without superior and sustained performance, according to sector and IBI level of innovativeness.

Table 10

Classification of 137 Innovative Firms According to Sector, IBI Level of Innovativeness and Presence ("Yes") or Absence ("No") of Superior and Sustained Performance

\begin{tabular}{lccccccccccc}
\hline Sector & \multicolumn{2}{c}{$\begin{array}{c}\text { Group 1: } \\
\text { high-tech }\end{array}$} & \multicolumn{2}{c}{$\begin{array}{c}\text { Group 2: } \\
\text { medium } \\
\text { high-tech }\end{array}$} & $\begin{array}{c}\text { Group 3: } \\
\text { medium low- } \\
\text { tech }\end{array}$ & $\begin{array}{c}\text { Group 4: } \\
\text { low-tech }\end{array}$ & & Total \\
\cline { 2 - 12 } & No & Yes & No & Yes & No & Yes & No & Yes & No & Yes \\
\hline Capital goods and services & 9 & 4 & 8 & 4 & - & - & - & - & 17 & 8 \\
Construction and transportation & - & - & - & - & 2 & 1 & - & - & 2 & 1 \\
Cyclical consumption & - & - & 1 & 3 & 8 & 12 & 1 & 2 & 10 & 17 \\
\hline
\end{tabular}


Table 10 (continued)

\begin{tabular}{lcccccccccc}
\hline Sector & $\begin{array}{c}\text { Group 1: } \\
\text { high-tech }\end{array}$ & $\begin{array}{c}\text { Group 2: } \\
\text { medium } \\
\text { high-tech }\end{array}$ & $\begin{array}{c}\text { Group 3: } \\
\text { medium low- } \\
\text { tech }\end{array}$ & $\begin{array}{c}\text { Group 4: } \\
\text { low-tech }\end{array}$ & Total \\
\cline { 2 - 13 } & No & Yes & No & Yes & No & Yes & No & Yes & No & Yes \\
\hline Non-cyclical consumption & - & - & - & - & - & 1 & 12 & 8 & 12 & 9 \\
Basic materials & - & - & 10 & 0 & 6 & - & 10 & 8 & 26 & 8 \\
Oil, gas and biofuels & - & - & 2 & 2 & - & - & - & - & 2 & 2 \\
IT & 4 & 3 & - & - & - & - & - & - & 4 & 3 \\
Telecommunications & - & - & 13 & 3 & - & - & - & - & 13 & 3 \\
\hline Total & 13 & 7 & 34 & 12 & 16 & 14 & 23 & 18 & 86 & 51 \\
\hline
\end{tabular}

Note. Source: Data collected for the study.

Based on disclosed ROA values, $51(37 \%)$ versus $86(63 \%)$ of the 137 firms in our sample displayed superior and sustained performance. Of these, as many as $17(\sim 33 \%)$ belonged to the cyclical consumption sector.

Subsequently, the collected data were submitted to the Kolmogorov-Smirnov test for normality and a test for equality of means. The results are shown in Table 11.

Table 11

Result of Kolmogorov-Smirnov Test for Normality

\begin{tabular}{lcc}
\hline Variable & $\boldsymbol{p}$-value & Reject $\boldsymbol{H}_{\mathbf{0}} \boldsymbol{?}$ \\
\hline Market assets & $0.000^{* * *}$ & Yes \\
Intellectual property assets & $0.000^{* * *}$ & Yes \\
Infrastructure assets & $0.000^{* * *}$ & Yes \\
Other intangibles & $0.000^{* * *}$ & Yes \\
\hline Total & $0.000^{* * *}$ & Yes \\
\hline
\end{tabular}

Note. Source: Data collected for the study.

$\dagger=p<0.10 ; *=p<0.05 ; * *=p<0.01 ; * * *=p<0.001$

As shown in Table 11, the null hypothesis was rejected for all variables. Since the distribution was non-normal in all cases ( $p<0.05$ ), a test for nonparametric variables (Mann-Whitney) was employed. The results are shown in Table 12 . 
Table 12

\section{Result of the Mann-Whitney Test}

\begin{tabular}{lcc}
\hline Variable & $\boldsymbol{p}$-value & Reject $\boldsymbol{H}_{\mathbf{0}} \boldsymbol{?}$ \\
\hline Market assets & 0.286 & No \\
Intellectual property assets & $0.006^{* * *}$ & Yes \\
Infrastructure assets & $0.009^{* * *}$ & Yes \\
Other intangibles & 0.434 & No \\
\hline Total & 0.481 & No \\
\hline
\end{tabular}

Note. Source: Data collected for the study.

$\dagger=\mathrm{p}<0.10 ; *=\mathrm{p}<0.05 ; * *=\mathrm{p}<0.01 ; * * *=\mathrm{p}<0.001$

Table 12 shows that, when comparing firms with and without superior and sustained performance, the null hypothesis could not be rejected, indicating statistical similarity between the mean values of the intangible assets in the categories market assets, other intangibles and total intangible assets $(p>0.05)$.

On the other hand, with regard to the categories intellectual property assets and infrastructure assets, the null hypothesis was rejected $(p<0.05)$ and the alternative hypothesis confirmed, indicating a significant difference between firms with and without superior and sustained performance.

Thus, firms with superior and sustained performance displayed significantly higher mean values in the categories intellectual property assets and infrastructure assets. According to Besanko, Dranove, Shanley and Schaefer (2006), financial earnings above the sector average confer a competitive advantage for a firm in a given market.

To our knowledge, no previous study has compared innovative firms with and without superior and sustained performance with regard to intangible assets segregated by category. Several authors (Carvalho et al., 2010; Kayo, 2002; Megna \& Klock, 1993; Perez \& Famá, 2006; Villalonga, 2004) have studied intangibility in general as a determinant of business performance and found investments in intangibles to be more prevalent in firms with superior and sustained performance.

The results of the test of correlation between investments in intangible assets (in BRL) and corporate performance (ROA) are shown in Table 13.

Table 13

Correlation Matrix

\begin{tabular}{lcccccc} 
& Performance & $\begin{array}{c}\text { Total } \\
\text { intangible } \\
\text { assets }\end{array}$ & $\begin{array}{c}\text { Market } \\
\text { assets }\end{array}$ & $\begin{array}{c}\text { Intellectual } \\
\text { property } \\
\text { assets }\end{array}$ & $\begin{array}{c}\text { Infrastructure } \\
\text { assets }\end{array}$ & $\begin{array}{c}\text { Other } \\
\text { intangibles }\end{array}$ \\
\hline Performance & 1 & & & & & \\
Total intangible assets & 0.033 & 1.000 & & & \\
Market assets BRL & 0.079 & $0.480^{* * *}$ & 1.000 & & \\
$\begin{array}{l}\text { Intellectual property } \\
\text { assets BRL }\end{array}$ & $0.138^{* * *}$ & $0.422^{* * *}$ & $0.481^{* * *}$ & 1.000 & \\
\hline
\end{tabular}

Continues 
Table 13 (continued)

\begin{tabular}{lcccccc} 
& Performance & $\begin{array}{c}\text { Total } \\
\text { intangible } \\
\text { assets }\end{array}$ & $\begin{array}{c}\text { Market } \\
\text { assets }\end{array}$ & $\begin{array}{c}\text { Intellectual } \\
\text { property } \\
\text { assets }\end{array}$ & $\begin{array}{c}\text { Infrastructure } \\
\text { assets }\end{array}$ & $\begin{array}{c}\text { Other } \\
\text { intangibles }\end{array}$ \\
\hline $\begin{array}{l}\text { Infrastructure assets } \\
\text { BRL }\end{array}$ & 0.063 & $0.320 * * *$ & $0.327 * * *$ & $0.376 * * *$ & 1.000 \\
Other intangibles BRL & 0.082 & $0.842 * * *$ & $0.675^{* * *}$ & $0.611 * * *$ & $0.431 * * *$ & 1.000 \\
\hline
\end{tabular}

Note. Source: Data collected for the study.

*** Correlation significant at $0.01 ; * *$ Correlation significant at $0.05 ; *$ Correlation significant at 0.10 .

As shown in Table 13, a non-significant correlation was observed between total investments in intangible assets and corporate performance. More specifically, performance was positively and significantly correlated with investments in intellectual property assets. However, the correlation between performance and intellectual property was weak (coefficients from 0.1 to 0.3 ).

In addition, using corporate performance (ROA) as dependent variable, regression models were developed to analyze the relation between the study variables. In the first regression model, the independent variables were the control variables company size, dummy sector and dummy innovation group (according to the IBI). In the second regression model, the independent variables included the same control variables and the variables representing categories of investment in intangible assets (according to Brooking, 1996). Finally, in the third regression model, the independent variables were the same control variables and total investment in intangible assets. Robust regressions were performed to prevent homoscedasticity. Variance inflation factor (VIF) analysis was used to rule out multicollinearity. The analysis yielded acceptable results (multicollinearity between 1 and 10), with VIF values below 4 in all cases.

The results of the robust regression analyzed with the ordinary least squares method are displayed in Table 14. The variables D7_IND and D3_INOV were excluded due to exact collinearity.

Table 14

\section{Regression Models}

\begin{tabular}{lccc}
\cline { 2 - 4 } & $\begin{array}{c}\text { Coefficients } \\
\text { Regression 1 }\end{array}$ & $\begin{array}{c}\text { Coefficients } \\
\text { Regression 2 }\end{array}$ & $\begin{array}{c}\text { Coefficients } \\
\text { Regression 3 }\end{array}$ \\
\hline Constant & $-33.64^{* * *}$ & $-33.70^{* * *}$ & $-33.45^{* * *}$ \\
Total intangible assets & - & - & -0.8487 \\
Market assets & - & -0.3960 & - \\
Intellectual property assets & - & 0.1858 & - \\
Infrastructure assets & - & -2.8000 & - \\
Other intangibles & - & 1.8403 & - \\
Size & $6.8430^{* * *}$ & $6.8019^{* * *}$ & $6.8210^{* * *}$ \\
Capital goods and services & -1.6867 & -1.3269 & -1.6828 \\
Construction and transportation & 2.5678 & 2.8413 & 2.4999 \\
Cyclical consumption & $-11.7863 *$ & $-11.4870^{*}$ & $-11.8304 *$ \\
Non-cyclical consumption & -5.7437 & -5.4291 & -5.7394 \\
\hline
\end{tabular}


Table 14 (continued)

\begin{tabular}{lccc}
\cline { 2 - 4 } & $\begin{array}{c}\text { Coefficients } \\
\text { Regression 1 }\end{array}$ & $\begin{array}{c}\text { Coefficients } \\
\text { Regression 2 }\end{array}$ & $\begin{array}{c}\text { Coefficients } \\
\text { Regression 3 }\end{array}$ \\
\hline Basic materials & $-4,6355$ & -4.3019 & -4.6399 \\
Oil, gas and biofuels & $-16.7836^{* * *}$ & $-16.4008^{* * *}$ & $-16.7091^{* * * *}$ \\
Telecommunications & $-9.8659^{*}$ & $-9.4824^{*}$ & $-9.7045^{*}$ \\
Innovation 1 & -0.2531 & 0.0699 & -0.1790 \\
Innovation 2 & -1.2719 & -1.3222 & -1.2986 \\
Innovation 4 & -1.2719 & -0.9526 & -0.9331 \\
F Test & $F=4.07$ & $F=3.88$ & $F=3.82$ \\
& Sig. $=0.000$ & Sig. $=0.000$ & Sig. $=0.000$ \\
$\mathrm{R}^{2}$ & 0.1015 & 0.1020 & 0.1016 \\
\hline
\end{tabular}

Note. Source: Data collected for the study.

*** Correlation significant at $0.01 ; * *$ Correlation significant at $0.05 ; *$ Correlation significant at 0.10 .

As shown in Table 14, corporate performance was not significantly correlated with any of the indicators of investment in intangible assets. However, performance was positively correlated with company size and negatively correlated with oil, gas and biofuels and, at the $10 \%$ level of significance, cyclical consumption, as indicated by the sign of the coefficient. Thus, firms in these sectors were less likely to perform well.

The $F$ test showed the three models to be significant, and $\mathrm{R}^{2}$ was $10.15 \%, 10.20 \%$ and $10.16 \%$, respectively, indicating the power of the models to explain the relation between the dependent and independent variables in each case.

The first model (control variables only) revealed a correlation between corporate performance and company size, oil, gas and biofuels, cyclical consumption and telecommunications. The correlation was positive for company size and negative for the remaining three variables.

The second regression (control variables + categories of investment in intangible assets according to Brooking, 1996) yielded similar results. Had the correlation between corporate performance and investment in intangible assets been significant, it would have been negative for investment in market assets and infrastructure and positive for investment in intellectual property and other intangibles, as indicated by the sign of the coefficient. In other words, investment in market assets and infrastructure assets had a negative influence on corporate performance, whereas investment in intellectual property assets and other intangibles, if significant, would have a positive influence on performance. Hence, not all the investments classified by Brooking (1996) were associated with improved performance.

The third regression (control variables + total investment in intangible assets) yielded similar results; i.e. no significant correlation between corporate performance and investment in intangible assets. However, had the correlation been significant, it would have been negative, as indicated by the sign of the coefficient. From Table 14 it may be inferred that had the total amount of investments in intangible assets been significant, it would have had a negative effect on corporate performance (the coefficient is negative). It would seem the coefficient was influenced by infrastructure assets, which yielded a high coefficient in the second regression, corresponding to a considerable negative effect on performance. For some of the control variables, no statistical significance was observed in any of the three regressions (capital goods and services, non-cyclical consumption, basic materials and construction and transportation). Construction and transportation was the only of these sectors which was associated with improved performance. Firms belonging to Innovation Groups 2 and 4 experienced loss of performance, indicating that inclusion in an innovative segment is not synonymous with better performance. Firms belonging to Innovation Group 1 displayed negative coefficients in the first and 
third regression only; when analyzed together with the variables of the amounts invested in each category of intangible assets, the coefficient was positive and, had it been significant, it would have contributed positively to corporate performance.

Based on the lack of evidence for a significant correlation between corporate performance and investment in intangible assets, our initial hypothesis that a positive relation exists between the composition of investments in intangible assets and the performance of innovative firms could not be confirmed. In addition, as shown by the test for equality of means, firms with and without superior and sustained performance only differed with regard to investment in intellectual property assets and infrastructure assets (investments were greater in firms without superior and sustained performance).

This contradicts the premises of RBV with regard to the dependence of these variables. However, it should be pointed out that, while investments in intangible assets per se could not be shown to influence corporate performance, other factors in synergy with such investments may explain the firms' superior and sustained performance.

Using ROA as a proxy for performance, we found that innovative firms with and without superior and sustained performance differed only with regard to the categories intellectual property assets and infrastructure assets, with higher mean values in the group of firms without superior and sustained performance. This finding calls into question the assumption of RBV and the claim of Villalonga (2004) and Perez and Famá (2006) that intangibility per se is a determining factor of superior and sustained performance.

However, the studies backing this claim were contextualized in a highly developed market (the US) subject to a legal system based on common law, whereas the present study was based on a sample of firms operating in an emerging economy (Brazil) subject to civil law and characterized by an unstable capital market and unsatisfactory implementation of corporate governance practices (Lopes \& Walker, 2008).

The results of an additional analysis revealed differences between mean values, indicating a relation between performance and investments in intellectual property assets and infrastructure assets. The results of the test for equality of means, showing that firms without superior and sustained performance invested more in intellectual property assets and infrastructure assets, are partly in agreement with Carvalho et al. (2010) who reported a negative relation between intangible assets and superior and sustained performance; in other words, in that study greater investments in intangible assets were negatively associated with corporate performance.

However, the findings of the present study contradict the results published by Ulrich and Smallwood (2005) who concluded, in light of RBV, that the possession of unique resources, especially intellectual property assets, improve corporate performance. Likewise, Ray et al. (2013) observed a relation between performance and IT-related infrastructure.

In their comparison of intangible asset-intensive versus tangible asset-intensive firms, Perez and Famá (2006) used stock market value, return on investment, economic value added and earnings spread as proxies for business performance. The authors concluded higher levels of intangibility were correlated with better performance. The present findings do not support this view since innovative firms without superior and sustained performance displayed greater mean values in the categories intellectual property assets and infrastructure assets (Table 8).

When seen in the light of the study of Roberts and Dowling (2002), the purpose of which was to analyze the relation between intangible assets and corporate reputation and superior and sustained performance, intangible assets may be considered inimitable, rare and valuable to the firm (Teixeira \& Popadiuk, 2003). In addition, because of their uniqueness, intangible assets can make a company stand out on the market, contribute to organizational management (Oening, 2010) and help achieve superior and sustained performance. Thus, corporate reputation becomes a strategic tool with which to outperform the competition and achieve sector leadership (Castro, 2009). 
In summary, in our sample of 137 innovative firms, investments in the categories intellectual property assets (the predominant category) and infrastructure assets - but not in the categories market assets, other intangibles and total intangible assets - were significantly greater in firms without superior and sustained performance.

\section{Conclusion}

Due to the effects of globalism, firms now need to be more effectively managed to remain competitive on the market and produce satisfactory results. Thus, above-average performance has become a priority for competitive firms. In general, scholars have extolled innovation as a highly influential factor in the maintenance of superior and sustained business performance. Investments in intangible assets are believed to determine growth and future creation of value for the organization.

In view of the importance attributed to intangible assets, the purpose of the present study was to investigate whether innovative firms with superior and sustained performance and firms without superior and sustained performance differ with regard to investments in intangible assets. In addition, we observed the existence of a relation between investments in intangible assets and the performance of innovative firms.

In our literature review, we found several studies identifying intangibility as a determining factor of business performance, but to our knowledge no previous study has evaluated the association between performance and intangible assets segregated by category.

The 137 firms in our sample - identified by the Brazilian Index of Innovation (IBI) as the most innovative in the country - were listed on BM\&FBovespa throughout the four-year study period. When assets were segregated according to Brooking's classification (1996), a significant association was observed between superior and sustained performance and mean investments in the categories intellectual property assets and infrastructure assets, but not for the categories market assets, other intangibles and total intangible assets.

The category intellectual property assets was the most representative in this sample of intangible asset-intensive (Kayo, 2002) and potentially innovative firms.

The performance of the innovative firms in our sample was positively correlated with investments in intellectual property assets, matching the findings of a number of RBV-based studies on assets in general (Megna \& Klock, 1993; Perez \& Famá, 2006; Villalonga, 2004) and specific types of assets (Ray, Xue, \& Barney, 2013; Ulrich \& Smallwood, 2005).

The fact that firms without superior and sustained performance displayed higher indicators of intangible assets does not imply that investment in intangible assets influences performance. In fact, overall, the sampled firms are investing increasing amounts in intangible assets, possibly under the influence of emerging markets practices.

We believe the intended purpose of the study was accomplished in that our findings confirm the importance of intangible assets to the maintenance of superior and sustained performance in innovative Brazilian firms. Clearly, the factors associated with corporate strategy constitute a highly relevant subject in need of continual analysis and investigation. It should be kept in mind that a firm's resources, capacities and targeted market are directly dependent on management practices and should be the object of running evaluations to secure the feedback required for adequate decision making.

However, caution is necessary when extrapolating our results: our sample was limited to a specific number of public firms traded on BM\&FBovespa and listed on the IBI ranking of innovative sectors, with unique characteristics and substantial investments in intangible assets. In addition, financial information was limited to information disclosed in accounting statements, and the definition of superior 
performance was based on only one proxy (ROA), which reflects corporate performance in terms of returns on a given asset, without taking into account aspects of the external market. Likewise, the choice of certain variables rather than others for the analysis may have influenced the results.

No less important is the fact that the period covered by the study coincides with important global economic events, especially the world financial crisis of 2008-2009, which is considered a watershed in capitalist economies, with inevitable impacts on corporate performance.

It should also be kept in mind that our results were based on the amounts disclosed in the intangible assets section of the accounting statements published by the firms in the sample. In light of the economic concept of intangible assets, some of the classifications of intangible assets used by the firms may appear inconsistent. Hence, the use of a different measure of investment in intangible assets could potentially have yielded different results. This observation suggests the need for further studies contemplating alternative measures.

Despite the rigorous application of methodology and the relevance of our findings, caution should be exercised with regard to the generalizability of our conclusions due to the unique characteristics of our sample and the metrics employed to quantify intangible assets and performance. Thus, we suggest conducting further studies based on larger samples and using additional information sources and performance measures. In addition, in future studies other statistical methods might be employed to identify associations between specific types of intangible assets and superior and sustained performance. In qualitative terms, the subject could be further explored in light of knowledge management informed by the approach of learning and knowledge creation and innovation projects. Finally, it would useful and potentially enlightening to probe the subject of intangibility from other measuring perspectives.

\section{References}

Almeida, M. A., \& Santos, J. F. dos (2008). Relação entre variáveis endógenas e a qualidade das práticas de governança corporativa das empresas brasileiras de capital aberto não listadas em bolsa. Revista de Informação Contábil, 2(4), 17-37.

Antunes, M. T. P. (2005). O capital intelectual segundo o entendimento de gestores de empresas brasileiras. Revista Brasileira de Gestão de Negócios, 7(19), 9-20. doi: 10.7819/rbgn.v7i19.46

Antunes, M. T. P. (2006). A controladoria e o capital intelectual: um estudo empírico sobre sua gestão. Revista Contabilidade \& Finanças, 17(41), 21-37. doi: 10.1590/S1519-70772006000200003

Antunes, M. T. P., \& Leite, R. S. (2008). Divulgação de informações sobre ativos intangíveis e sua utilidade para analistas de investimentos. Revista Universo Contábil, 4(4), 22-38. doi: 10.1590/S1678-69712010000500005

Assaf, A., Neto (2009). Finanças corporativas e valor (4a ed.). São Paulo: Atlas.

Barney, J. (1991). Firm resources and sustained competitive advantage. Journal of Management, 17(1), 99-120. doi: 10.1177/014920639101700108

Barney, J. B., \& Hesterly, W. S. (2007). Administração estratégica e vantagem competitiva. São Paulo: Pearson Prentice Hall.

Basso, L. F. C., \& Kimura, H. (2010). O conceito de risco na visão baseada em recursos (RBV): uma análise exploratória. Revista de Administração Mackenzie, 11(5), 82-105. doi: 10.1590/S167869712010000500005

Besanko, D., Dranove, D., Shanley, M., \& Schaefer, S. (2006). A economia da estratégia. Porto Alegre: Bookman. 
Bollen, L., Vergauwen, P., \& Schnieders, S. (2005). Linking intellectual capital and intellectual property to company performance. Management Decision, 43(9), 1161-1185. doi: $10.1108 / 00251740510626254$

Bomfim, P. R. C. M., Almeida, R. S. de, Gouveia, V. A. L., Macedo, M. A. da S., \& Marques, J. A. V. da C. (2011). Utilização de análise multivariada na avaliação do desempenho econômicofinanceiro de curto prazo: uma aplicação no setor de distribuição de energia elétrica. Revista ADM. MADE, 15(1), 75-92.

Bortoluzzi, S. C., Lyrio, M. V. L., \& Ensslin, L. (2008, novembro). Avaliação de desempenho econômico-financeiro: uma proposta de integração de indicadores contábeis tradicionais por meio da metodologia multicritério de apoio à decisão construtivista. Anais do Congresso Brasileiro de Custos, Curitiba, PR, Brasil, 15.

Bou, J. C., \& Satorra, A. (2007). The persistence of abnormal returns at industry and firm levels: evidence from Spain. Strategic Management Journal, 28(7), 707-722. doi: 10.1002/smj.586

Brito, L. A. L., \& Vasconcelos, F. C. (2004). Performance of Brazilian companies: year effects, line of business and individual firms. Brazilian Administration Review, 1(1), 1-15. Retrieved from http://www.scielo.br/pdf/bar/v1n1/v1n1a02.pdf. doi: 10.1590/S1807-76922004000100002

Brooking, A. (1996). Intellectual capital: core asset for the third millennium enterprise. Boston, USA: Thomson Publishing Inc.

Brozen, Y. (1971). Bain's concentration and rates of return revisited. Journal of Law and Economics, 14(2), 351-369.

Camargo, E. G. (2008). Sistema da qualidade, inovação tecnológica e competitividade nas indústrias eletrônicas e de software de Curitiba e Região Metropolitana (Dissertação de mestrado). Programa de Pós-Graduação em Administração - Doutorado e Mestrado, Universidade Federal do Paraná, Curitiba, PR, Brasil. Retrieved from http://dspace.c3sl.ufpr.br/dspace/bitstream/handle/1884/18544/DISSERTACAO.pdf?sequence=1

Carneiro, J. M. T., Silva, J. F. da, Rocha, A. da, \& Dib, L. A. da R. (2007). Building a better measure of business performance. RAC-Eletrônica, 1(2), 114-135. Retrieved from http://www.anpad.org.br/periodicos/arq_pdf/a_639.pdf

Carvalho, F. M., \& Ensslin, S. R. (2006, julho). A evidenciação voluntária do capital intelectual: um estudo revisionista do contexto internacional. Anais do Congresso USP de Controladoria $e$ Contabilidade, São Paulo, SP, Brasil, 7.

Carvalho, F. M. de, Kayo, E. K., \& Martin, D. M. L. (2010). Tangibilidade e intangibilidade na determinação do desempenho persistente de firmas brasileiras. Revista de Administração Contemporânea, 14(5), 871-889. Retrieved from http://www.scielo.br/pdf/rac/v14n5/v14n5a07.pdf. doi: 10.1590/S1415-65552010000500007.

Castro, D. J. (2009, agosto). Em busca da "reputação corporativa": perspectivas conceituais e metodológicas. Anais dos Seminários em Administração, São Paulo, SP, Brasil, 12.

Chauvin, K. W., \& Hirschey, M. (1993). Adversiting, R\&D expenditures and the market value of the firm. Financial Management, 22(4), 128-140. doi: 10.2307/3665583

Colauto, R. D., Nascimento, P. S., Avelino, B. C., \& Bispo, O. N. A. (2009). Evidenciação de ativos intangíveis não adquiridos nos relatórios da administração das companhias listadas nos níveis de governança corporativa da Bovespa. Contabilidade Vista e Revista, 20(1), 142-169.

Comitê de Pronunciamentos Contábeis. (2008). Pronunciamento técnico CPC 04 - ativo intangível. Retrieved from http://www.cpc.org.br/mostraOrientacao.php?id=27. 
Comitê de Pronunciamentos Contábeis. (2010). Pronunciamento técnico CPC 04 (R1) - ativo intangivel. Retrieved from http://www.cpc.org.br/pdf/CPC04_R1.pdf.

Connolly, R. A., \& Hirschey, M. (2005). Firm size and the effect of R\&D on Tobin's q. $R \& D$ Management, 35(2), 217-223. doi: 10.1111/j.1467-9310.2005.00384.x

Crisóstomo, V. L. (2009). Ativos intangíveis: estudo comparativo dos critérios de reconhecimento, mensuração e evidenciação adotados no Brasil e em outros países. Contabilidade, Gestão e Governança, 12(1), 50-68.

Cunha, J. V. A., \& Coelho, A. C. (2007). Regressão linear múltipla. In L. J. Corrar, E. Paulo, \& J. M. Dias, Filho (Coords.), Análise multivariada: para os cursos de administração, ciências contábeis e economia (pp. 131-231). São Paulo: Atlas.

Edvinsson, L., \& Malone, M. S. (1998). Capital intelectual: descobrindo o valor real de sua empresa pela identificação de seus valores internos. São Paulo: Makron Books.

Ensslin, S. R., \& Carvalho, F. N. de (2007). Voluntary disclosure of intellectual capital in the Brazilian context: an investigation informed by the international context. International Journal of Accounting, Auditing and Performance Evaluation, 4(4/5), 478-500. doi: 10.1504/IJAAPE.2007.017089

Fávero, L. P. L., Belfiore, P., Silva, F. L., \& Chan, B. L. (2009). Análise de dados: modelagem multivariada para tomada de decisões. São Paulo: Campus.

Flamholtz, E. (1985). Human resource accounting. London: Jossey-Bass Publishers.

Freundenberg, M. (2003). Composite indicators of country performance: a critical assessment [STI Working Paper 2003/16]. Industry Issues. Retrieved from https://www.itu.int/osg/spu/ni/wsisbridges/linked_docs/Background_papers/otherdocs/OECD_ WP_2003_16.pdf

Furtado, A., \& Quadros, R. (2006). Construindo o IBI. Inovação Uniemp, 2(3), 26-27.

Furtado, A., Quadros, R., \& Domingues, S. A. (2007). Intensidade de P\&D das empresas brasileiras. Inovação Uniemp, 3(6), 26-27.

Furtado, A., Quadros, R., Domingues, S. A., Camillo, E., Inácio, E., Jr., \& Righetti, S. (2007). IBI - o ranking das empresas. Inovação Uniemp, 3(3), 30-35.

Furtado, A., Quadros, R., Righetti, S., Inácio, E., Jr., Domingues, S. A., \& Camillo, E. (2007). Índice Brasil de inovação: manual informativo sobre o procedimento de adesão das empresas [Manual]. Unicamp/IG/DPCT, Labjor, Campinas, SP, Brasil.

Gallon, A. V., Lyrio, M. V. L., \& Ensslin, S. R. (2008). Gerenciamento do capital intelectual de uma EBT incubada: a contribuição da metodologia multicritério de apoio à decisão construtivista. Anais do Encontro Nacional da Associação Nacional de Pós-Graduação e Pesquisa em Administração, Rio de Janeiro, RJ, Brasil, 32.

Grant, R. M. (1991). The resource-based theory of competitive advantage: implications for strategy formulation. California Management Review, 33(3), 114-135.

Hendriksen, E. S., \& Van Breda, M. F. (1999). Teoria da contabilidade. São Paulo: Atlas.

Hillman, A. J., \& Keim, G. D. (2001). Shareholder value, stakeholder management, and social issues: What's the bottom line?. Strategic Management Journal, 22(2), 125-139. doi: 10.1002/10970266(200101)22:2<125::AID-SMJ150>3.0.CO;2-H 
Hoog, W. A. Z. (2008). Fundo de comércio goodwill em: apuração de haveres, balanço patrimonial, dano emergente, lucro cessante, locação não residencial. Curitiba: Juruá Editora.

Inácio, E., Jr., \& Quadros, R. (2006). Apresentando a fórmula do IBI. Inovação Uniemp, 2(5), 26-27.

Inácio, E., Jr., \& Quadros, R. (2008). Proposição de um novo método de seleção de micro, pequenas e médias empresas de base tecnológica (MPEBT). Anais do Encontro de Estudos sobre Empreendedorismo e Gestão de Pequenas Empresas, São Paulo, SP, Brasil, 5.

Instituto Brasileiro de Geografia e Estatística. (2006). Pesquisa de inovação tecnológica - Pintec 2005: pesquisa de inovação. Rio de Janeiro: IBGE.

International Accounting Standards. (n.d.). International Accounting Standard (IAS) 38. Retrieved from http://www.iasplus.com/en/standards/ias/ias38

International Accounting Standards. (2003). International Accounting Standard (IAS) 21. Retrieved from http://www.iasplus.com/en/standards/ias/ias21

Iudícibus, S. de, Martins, E., Gelbcke, E. R., \& Santos, A. dos (2013). Manual de contabilidade societária: aplicável a todas as sociedades de acordo com as normas internacionais e do CPC (2a ed.). São Paulo: Atlas.

Kaplan, R. S., \& Norton, D. P. (1996). The balanced scorecard: translating strategy into action. Boston: Harvard Business School.

Kaufmann, L., \& Schneider, Y. (2004). Intangibles: a synthesis of current research. Journal of Intellectual Capital, 5(3), 366-388. doi: 10.1108/14691930410550354

Kayo, E. K. (2002). A estrutura de capital e o risco das empresas tangível e intangível intensivas: uma contribuição ao estudo da valoração de empresas (Tese de doutorado). Universidade de São Paulo, São Paulo, SP, Brasil. Retrieved from http://www.teses.usp.br/teses/disponiveis/12/12139/tde05032003-194338/publico/teseeduardokayo.pdf

Kayo, E. K., Patrocínio, M. R., \& Martin, D. M. L. (2009). Intangibilidade e criação de valor em aquisições: o papel moderador do endividamento. Revista de Administração da Universidade de São Paulo, 44(1), 59-69.

Kayo, E. K., Teh, C. C., \& Basso, L. F. C. (2004). A influência dos ativos intangíveis sobre a estrutura de capital. Anais do Encontro Nacional da Associação Nacional de Pós-Graduação e Pesquisa em Administração, Curitiba, PR, Brasil, 28.

Kimura, H., \& Suen, A. S. (2003). Ferramentas de análise gerencial baseadas em modelos de decisão multicriteriais. RAE-Eletrônica, 2(1), 1-18. Retrieved from http://www.scielo.br/pdf/raeel/v2n1/v2n1a07.pdf

Kohler, E. L. (1957). A dictionary for accountants. New York: Prentice-Hall.

Kor, Y. Y., \& Mahoney, J. T. (2004). Edith Penrose's (1959) contributions to the resource-based view of strategic management. Journal of Management Studies, 41(1), 183-191. doi: 10.1111/j.14676486.2004.00427.x

Kot, E. M. (2009). How to conduct the audit of intellectual capital in Polish tourism business?. Journal of Knowledge Management, 7(4), 459-468.

Lee, R. P., \& Chen, Q. M. (2009). The immediate impact of new product introductions on stock price: the role of firm resources and size. Journal of Product Innovation Management, 26(1), 97-107. doi: 10.1111/j.1540-5885.2009.00337.x 
Lei n. 11.638, de 28 de dezembro de 2007. (2007). Altera e revoga dispositivos da Lei n. 6.404, de 15 de dezembro de 1976, e da Lei n. 6.385, de 7 de dezembro de 1976, e estende às sociedades de grande porte disposições relativas à elaboração e divulgação de demonstrações financeiras. Diário Oficial da União. Brasília, DF, Brasil. Retrieved from http://www.presidencia.gov.br/ccivil_03/_Ato2007-2010/2007/Lei/L11638.htm

Lev, B. (2001). Intangibles: management, measurement, and reporting. Washington: Brookings Institution Press.

Lima, A. C., \& Carmona, C. U. (2011). Determinantes da formação do capital intelectual nas empresas produtoras de tecnologia da informação e comunicação. Revista de Administração Mackenzie, 12(1), 112-138. doi: 10.1590/S1678-69712011000100005

Lopes, A. B., \& Walker, M. (2008). Firm-level incentives and the informativeness of accounting reports: an experiment in Brazil [Working paper]. Retrieved from http://papers.ssrn.com/sol3/papers.cfm?abstract_id=1095781

Lopes, D. P. T., \& Barbosa, A. C. Q. (2010). Inovação gerencial e organizacional no Brasil: uma análise a partir da pesquisa de inovação tecnológica. Anais dos Seminários sobre a Economia Mineira, Belo Horizonte, MG, Brasil, 14.

Macedo, M. A. S. da, Machado, M. R., Machado, M. A. V., \& Mendonça, P. H. C. (2013). Impacto da convergência às normas contábeis internacionais no Brasil sobre o conteúdo informacional da contabilidade. Revista de Educação e Pesquisa em Contabilidade, 7(3), 222-239.

Machado, J. H., \& Famá, R. (2011). Ativos intangíveis e governança corporativa no mercado de capitais brasileiro. Revista Contemporânea de Contabilidade, 8(16), 89-110.

Marr, B., Schiuma, G., \& Neely, A. (2004). The dynamics of value creation: mapping your intellectual performance drivers. Journal of Intellectual Capital, 5(2), 312-325. doi: $10.1108 / 14691930410533722$

McGahan, A. M., \& Porter, M. E. (2002). What do we know about variance in accounting profitability?. Management Science, 48(7), 834-851. doi: 10.1287/mnsc.48.7.834.2816

Megna, P., \& Klock, M. (1993). The impact of intangible capital on Tobin's q in the semiconductor industry. The American Economic Review, 83(2), 265-269.

Mintzberg, H. (1973). The nature of managerial work. New York: Harper \& Row.

Mueller, D. C. (1977). The persistence of profits above the norm. Economica, 44(176), 369-380. doi: $10.2307 / 2553570$

Nascimento, E. M., Oliveira, M. C. de, Marques, V. A., \& Cunha, J. V. A. da (2012). Ativos intangíveis: análise do impacto do grau de intangibilidade nos indicadores de desempenho empresarial. Enfoque: Reflexão Contábil, 31(1), 37-52. doi: 10.4025/enfoque.v31i1.10586

National Institute of Science and Technology Policy. (1995). Science and technology indicators 1994: a systematic analysis of science and technology activities in Japan [NISTEP Report, n.37]. Retrieved from http://www.nistep.go.jp/achiev/ftx/eng/rep037e/pdf/rep037e.pdf

Neely, A., Gregory, M., \& Platts, K. (1995). Performance measurement system design: a literature review and research agenda. International Journal of Operations \& Production Management, 15(4), 80116. doi: $10.1108 / 01443579510083622$

Nonaka, I., \& Takeuchi, H. (1997). Criação de conhecimento na empresa: como as empresas japonesas geram a dinâmica da inovação. Rio de Janeiro: Campus. 
Oening, K. S. (2010). Pluralismo teórico na gestão estratégica: a compreensão da vantagem competitiva a partir da harmonização de perspectivas antagônicas. Revista de Negócios, 15(1), 45-56. doi: $10.7867 / 1980-4431.2010 \mathrm{v} 15 \mathrm{n} 1 \mathrm{p} 45-56$

Organization for Economic Co-operation and Development. (2005). Oslo manual: proposed guidelines for collecting and interpreting technological innovation data [Manual]. OECD, Paris.

Oyadomari, J. C. T., Cardoso, R. L., Silva, B., O. T. da, \& Perez, G. (2010). Sistemas de controle gerencial: estudo de caso comparativo em empresas inovadoras no Brasil. Revista Universo Contábil, 6(4), 21-34. doi: 10.4270/ruc.2010429

Pacheco, V. (2005). Mensuração e divulgação do capital intelectual nas demonstrações contábeis: teoria e empiria (Tese de Doutorado). Departamento de Engenharia de Produção, Universidade Federal de Santa Catarina, Florianópolis, SC, Brasil.

Penrose, E. T. (1959). The theory of the growth of the firm. Oxford: Oxford University.

Penrose, E. T. (2006). A teoria do crescimento da firma. Campinas: Editora da Unicamp.

Perez, M. M., \& Famá, R. (2006). Ativos intangíveis e o desempenho empresarial. Revista Contabilidade \& Finanças, 17(40), 7-24. doi: 10.1590/\$1519-70772006000100002

Peteraf, M. A. (1993). The cornerstones of competitive advantage: a resource-based view. Strategic Management Journal, 14(3), 179-191. doi: 10.1002/smj.4250140303

Petkov, R. R. (2011). The current financial crisis and its potential impact on internally generated intangible assets. International Journal of Business and Management, 6(3), 37-44. doi: 10.5539/ijbm.v6n3p37

Petty, R., \& Guthrie, J. (2000). Intellectual capital literature review: measurement, reporting and management. Journal of Intellectual Capital, 1(2), 155-176. doi: 10.1108/14691930010348731

Quadros, R., \& Furtado, A. (2007). Índice Brasil de Inovação: a próxima etapa. Inovação Uniemp, 3(5), 26-27.

Ramos, M. Y. (2008). Evolução e novas perspectivas para a construção e produção de indicadores de ciência, tecnologia e inovação [Número Especial]. Encontros Bibli, 1-23. doi: 10.5007/15182924.2008v13nesp1p1

Ray, G., Xue, L., \& Barney, J. B. (2013). Impact of information technology capital on firm scope and performance: the role of asset characteristics. Academy of Management Journal, 56(4), 11251147.

Rezende, Y. (2001). Informação para negócios: os novos agentes do conhecimento e a gestão do capital intelectual. Caderno de Pesquisas em Administração, 8(1), 11-21.

Richardson, R. J. (2007). Pesquisa social: métodos e técnicas (3a ed.). São Paulo: Atlas.

Righetti, S., \& Pallone, S. (2007). Consolidando também o conceito de inovação tecnológica. Inovação UNIEMP, 3(4), 26-27.

Ritta, C. O., \& Ensslin, S. R. (2010). Investigação sobre a relação entre ativos intangíveis e variáveis financeiras: um estudo nas empresas brasileiras pertencentes ao Índice Ibovespa nos anos de 2007 e 2008. Anais do Congresso USP de Controladoria e Contabilidade, São Paulo, SP, Brasil, 10.

Roberts, P. W., \& Dowling, G. R. (2002). Corporate reputation and sustained superior financial performance. Strategic Management Journal, 23(12), 1077-1093. doi: 10.1002/smj.274 
Rocha, D. (2009). Uma análise sobre o prêmio fornecido pelas patentes às firmas brasileiras (Dissertação de mestrado). Departamento de Economia, Setor de Ciências Sociais Aplicadas, Universidade Federal do Paraná, Curitiba, PR, Brasil. Retrieved from http://dspace.c3sl.ufpr.br/dspace/bitstream/handle/1884/23447/Dissertacao.pdf?sequence=1

Rumelt, R. P. (1991). How much does industry matter?. Strategic Management Journal, 12(3), 167-185. doi: $10.1002 / \mathrm{smj} .4250120302$

Santos, E. S. (2012). Análise dos impactos dos CPCs da primeira fase de transição para o IFRS no Brasil: um exame dos ajustes aos resultados nas DFPS de 2008. Revista de Contabilidade $e$ Organizações, 6(15), 23-43. doi: http://dx.doi.org/10.11606/rco.v6i15.52655

Santos, J. G. C. dos, Silva, L. S., Gallon, A. V., \& De Luca, M. M. M. (2011). Ativos Intangíveis de empresas inovadoras. Revista Ciências Sociais em Perspectiva, 10(18), 85-108.

Santos, J. G. C. dos, Silva, L. S., Gallon, A. V., \& De Luca, M. M. M. (2012). Intangibilidade e inovação em empresas no Brasil. Revista de Administração e Inovação, 9(2), 197-221. doi: 10.5773/rai.v9i2.762

Santos, J. G. C. dos, Vasconcelos, A. C. de, \& De Luca, M. M. M. (2013). Perfil da inovação e da internacionalização de empresas transnacionais. Revista de Administração e Inovação, 10(1) 198211. doi: $10.5773 /$ rai.v1i1.1103

Santos, J. L. dos, \& Schmidt, P. (2002). Análise e evidenciação contábil da propriedade intelectual. Revista ConTexto, 2(3), 1-11.

Schmidt, P. (2002). Controladoria: agregando valor para a empresa. Porto Alegre, RS: Bookman.

Schimdt, P., \& Santos, J. L. dos (2002). Avaliação de ativos intangíveis. São Paulo: Atlas.

Schmalensee, R. (1985). Do markets differ much?. The American Economic Review, 75(3), 341-351.

Silva, M. F. de O. (2009). A vantagem competitiva das nações e a vantagem competitiva das empresas: a localização e importante? (Tese de doutorado). Pontifícia Universidade Católica do Rio de Janeiro, Rio de Janeiro, RJ, Brasil.

Stewart, T. A. (1999). Intellectual capital: the new wealth of organizations. New York: Doubleday.

Surroca, J., Tribó, J. A., \& Waddock, S. (2010). Corporate responsibility and financial performance: the role of intangible resources. Strategic Management Journal, 31(5), 463-490. doi: $10.1002 / \mathrm{smj} .820$

Sveiby, K. E. (1997). The new organizational wealth: managing \& measuring knowledge-based assets. San Francisco: Berrett-Koehler Publishers.

Teece, D. J., Pisano, G., \& Shuen, A. (1997). Dynamic capabilities and strategic management. Strategic Management Journal, 18(7), 509-533. doi: 10.1002/(SICI)1097-0266(199708)18:7<509::AIDSMJ882>3.0.CO;2-Z

Teixeira, J. P., Petri, S. M., \& Marques, T. O. de (2012). O valor da marca como um ativo intangível: um estudo de caso da WEG S.A. Revista de Contabilidade do Mestrado em Ciências Contábeis da UERJ, 17(2), 45-67.

Teixeira, M. L. M., \& Popadiuk, S. (2003). Confiança e desenvolvimento de capital intelectual: o que os empregados esperam de seus líderes? Revista de Administração Contemporânea, 7(2), 73-92. doi: $10.1590 /$ S1415-65552003000200005 
Tironi, L. F., \& Cruz, B. O. de (2008). Inovação incremental ou radical: há motivos para diferenciar? Uma abordagem com dados da Pintec (Texto para discussão, No 1360). Rio de Janeiro, RJ: Ipea.

Ulrich, D., \& Smallwood, N. (2005). HR's new ROI: return on intangibles. Human Resource Management, 44(2), 137-142.

United Nations Development Programme. (2001). Human development report 2001 - making new technologies work for human development. Oxford, UK: Oxford University Press. Retrieved from http://hdr.undp.org/sites/default/files/reports/262/hdr_2001_en.pdf

Vasconcelos, A. C. de, Santos, R. F., De Luca, M. M. M., \& Cunha, J. V. A. da (2013). Longitudinal study of the degree of intangibility of the largest banks in Brazil. Revista de Contabilidade $e$ Organizações, 7(19), 40-58. doi: 10.11606/rco.v7i19.55516

Villalonga, B. (2004). Intangible resources, Tobin's q and sustainability of performance differences. Journal of Economic Behavior \& Organization, 54(2), 205-230. doi: 10.1016/j.jebo.2003.07.001

Wernerfelt, B. (1984). A resource-based view of the firm. Strategic Management Journal, 5(2), 171180. doi: $10.1002 / \mathrm{smj} .4250050207$ 